\title{
Synthesis of 3-Bromotetronamides via Amination of 3,4-Dibromofuran-2(5H)-one
}

\author{
Silvio Cunha, ${ }^{*, a, c}$ Caio C. Oliveira ${ }^{a, c}$ and José R. Sabino ${ }^{b}$ \\ ${ }^{a}$ Instituto de Química and 'Instituto Nacional de Ciência e Tecnologia - INCT em Energia e \\ Ambiente, Universidade Federal da Bahia, Campus de Ondina, 40170-290 Salvador-BA, Brazil

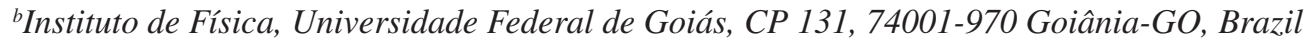

\begin{abstract}
Este trabalho descreve a síntese de dez tetronamidas em bons rendimentos através da reação da 4-dibromofuran-2 $(5 H)$-ona, obtida do furfural, com aminas primárias e secundárias. As aminas aromáticas foram mais toleradas que as alifáticas e as heteroaromáticas. Foram determinadas as estruturas cristalinas de cinco derivados.
\end{abstract}

This work describes the direct synthesis of 3-bromotetronamides in good yields through the reaction of 3,4-dibromofuran-2(5H)-one, obtained from furfural, with primary and secondary amines. Aromatic amines were more tolerated than aliphatic and heteroaromatic ones. The X-ray structures of five derivatives are described.

Keywords: enaminones, tetronamides, butenolides

\section{Introduction}

The synthesis of functionalized tetronamides is a theme of ongoing research activity, and this interest is due to the synthetic applications of such compounds, mainly in heterocyclic synthesis. ${ }^{1}$ A particular class of synthetically useful tetronamides are the 3-halo derivatives. However, most of the available protocols for the synthesis of 3-halotetronamides are based on the direct halogenation of a preformed enaminone, employing halogenation's reagents such as $\mathrm{ICl}, \mathrm{NBS}, \mathrm{Br}_{2}, \mathrm{I}_{2}, \mathrm{I}(\mathrm{py})_{2} \mathrm{BF}_{4}$ and benzyltrimetylammonium dichloroiodate $\left(\mathrm{BTMA} . \mathrm{ICl}_{2}\right){ }^{2}$

Cyclic enaminones are especially attractive in the formation of bicyclic compounds. ${ }^{3}$ In this context, tetronamides have embedded in their structure the $\mathrm{N}-\mathrm{C}=\mathrm{C}-\mathrm{C}=\mathrm{O}$ enaminone moiety, and recently they have emerged as a latent acyclic enaminone in the formal aza$[3+3]$ cycloaddition reaction. ${ }^{4}$ However, the synthesis of 3 -halotetronamides unsubstituted at position 5 is scarcely described, being limited to the reaction of $\alpha$-halotetronic acid with an amine ${ }^{5}$ or by direct halogenation of tetranamides. ${ }^{6}$ Thus, practical synthetic approaches to this class of compound would be beneficial.

In our ongoing investigation on the chemistry of enaminones, ${ }^{7}$ we envisioned herein a direct route

\footnotetext{
*e-mail: silviodc@ufba.br
}

to 3-bromotetronamides (4-amino-3-bromo-2(5H) furanones), which are a special class of cyclic compound because they present both aspects mentioned above, i.e., the embedded enaminone moiety, and the bromide atom at the alpha position. Besides, this study represents an approach to 3-bromotetronamides from furfural, an attractive starting material obtained from renewable biomass. In this way, the furfural derivative of choice was the 3,4-dibromofuran-2(5H)-one $\mathbf{1}$, which is easily prepared in $70 \%$ overall yield by the reaction of furfural with bromine in water, affording mucobromic acid (commercially available also). ${ }^{8}$ This late was reduced affording 1 in $87-96 \%$ yield, Scheme 1, employing a recently described method by Bellina and Rossi. ${ }^{9}$ It should be pointed out that the reactions where $\mathbf{1}$ is employed as electrophile is scarcely described, being limited to palladium cross-coupling reactions, ${ }^{10}$ or only to morpholine as nucleophile and expensive base $\left(\mathrm{Cs}_{2} \mathrm{CO}_{3}\right){ }^{11}$

\section{Results and Discussion}

The amination of $\mathbf{1}$ has proved to be a difficult task due to its propensity to forming polymeric material, probably thought the corresponding homoenolate, even in the presence of weak bases. Thus, complex mixtures were formed with pyrrolidine, piperidine, pyridine, 2-aminopyridine, 2-aminothiazol, benzylamine, 


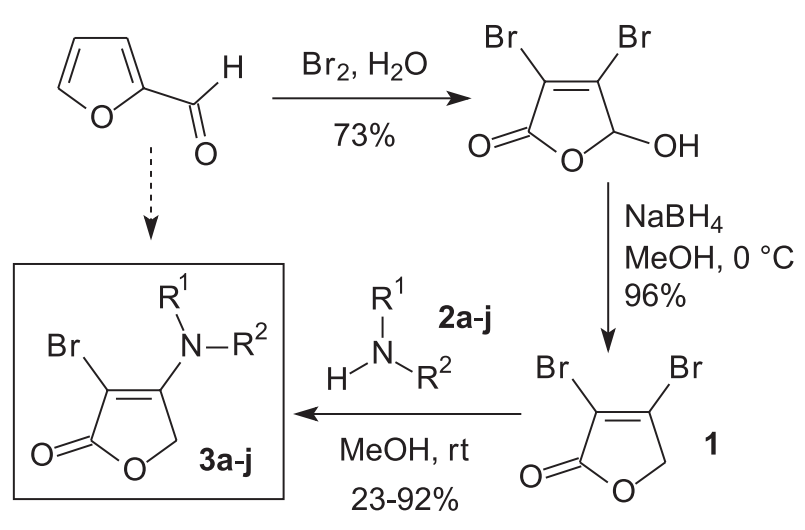

Scheme 1.

dibenzylamine, piperazine, cyclohexylamine and ethyl 3-aminocrotonate.

To test the possibility of a direct synthesis of 3-bromotetronamides, equimolar amounts of $\mathbf{1}$ and morpholine were reacted in diverse solvents and temperatures, but the starting material $\mathbf{1}$ was always detected by TLC. Employing 2 equiv. of morpholine in diethyl ether $(24 \mathrm{~h})$ or acetone $(2.5 \mathrm{~h})$ at room temperature complex mixture was formed, but in acetone at low temperature $\left(0^{\circ} \mathrm{C}\right)$ tetronamide 3a could be obtained in modest 35\% yield. However, when the reaction was carried out in methanol at room temperature, excellent yield was obtained (Table 1, entry 1). With this optimal condition in hand, it was extended to a representative spectrum of aromatic amines, and yields were good to all of them, but some ortho substituted ones (entries 6, 8 and 10). Mechanistically, formation of all 3-bromotetronamides 3a-f is a nucleophilic substitution by an addition-elimination pathway.

The use of 2 equiv. of amines can be a serious drawback when expensive or no commercial amines are necessary. To circumvent this limitation, one can imagine the use of one equiv. of a trivial weak base to act as $\mathrm{HBr}$ scavenger. Due to the decomposition of butenolide $\mathbf{1}$ in basic medium, we investigated its stability in methanolic solution of equimolar amounts of $\mathbf{1}$ and $\mathrm{Et}_{3} \mathrm{~N}, \mathrm{Na}_{2} \mathrm{CO}_{3}$ and $\mathrm{NaHCO}_{3}$. Compound $\mathbf{1}$ was completely decomposed after $4 \mathrm{~h}$ to the two first bases, and after $24 \mathrm{~h}$ to the late. Because reaction of $\mathbf{1}$ and aromatic amines is a slow one, we choose $\mathrm{NaHCO}_{3}$ as additive.

Fortunately, the amount of amines $\mathbf{2}$ could be reduced to 1 equiv. and comparable yields of $\mathbf{3}$ were obtained when the reaction was carried out in the presence of 1 equiv. of $\mathrm{NaHCO}_{3}$ (entries 1, 3, 5, 7, Table 1). In general, anilines with para substituents afforded better yields and shorter reaction time than ortho substituted ones for both electron releasing and electron withdrawing groups (compare entries 3-8). Hence, a diversity of 3-bromotetronamides could be prepared, but the methodology presents some limitations, because no reaction was observed with 4-nitroaniline, diphenylaniline, 2,4-dichloroaniline and glycine, being furanone 1 quantitatively recovered.

Curiously, in the ${ }^{1} \mathrm{H}$ NMR spectrum of $\mathbf{3 c}$, the signal of the aromatic hydrogens show up as a singlet integrated

Table 1. Isolated 3-bromotetronamide yields
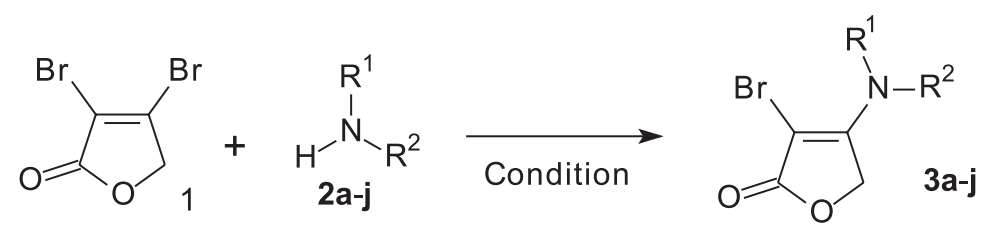

\begin{tabular}{|c|c|c|c|c|}
\hline \multirow{2}{*}{ entry } & \multirow{2}{*}{ Compound } & Amine 2 & Yield / (\%) & time / $\mathrm{h}$ \\
\hline & & $\mathrm{R}^{1} / \mathrm{R}^{2}$ & \multicolumn{2}{|c|}{ Condition $\mathrm{A}(\text { and } \mathrm{B})^{\mathrm{a}}$} \\
\hline 1 & 3a & $\mathrm{CH}_{2} \mathrm{CH}_{2} \mathrm{OCH}_{2} \mathrm{CH}_{2}$ & $92(65)$ & $24(88)$ \\
\hline 2 & $3 \mathbf{b}$ & $\mathrm{H} / \mathrm{Ph}$ & 89 & 22 \\
\hline 3 & $3 c$ & $\mathrm{H} / p-\mathrm{CH}_{3} \mathrm{Ph}$ & $80(87)$ & $14(200)$ \\
\hline 4 & 3d & $\mathrm{H} / o-\mathrm{CH}_{3} \mathrm{Ph}$ & 72 & 288 \\
\hline 5 & $3 e$ & $\mathrm{H} / p-\mathrm{CH}_{3} \mathrm{OPh}$ & $82(78)$ & $5(6)$ \\
\hline 6 & $3 f$ & $\mathrm{H} / o-\mathrm{CH}_{3} \mathrm{OPh}$ & 61 & 216 \\
\hline 7 & $3 g$ & $\mathrm{H} / p-\mathrm{ClPh}$ & $78(87)$ & $73(44)$ \\
\hline 8 & $3 \mathbf{h}$ & $\mathrm{H} / o-\mathrm{ClPh}$ & 23 & 120 \\
\hline 9 & $3 \mathbf{i}$ & $\mathrm{H} / o-\mathrm{NH}_{2} \mathrm{Ph}$ & 75 & 14 \\
\hline 10 & $\mathbf{3 j}$ & H / $\alpha$-naphthyl & 57 & 168 \\
\hline
\end{tabular}

${ }^{\mathrm{a}}$ Condition A: 2 equiv. of 2; Condition B: 1 equiv. of 2 and 1 equiv. of $\mathrm{NaHCO}_{3}$. 
to four hydrogens, and not as the typical pair of doublets expected for para substituted aromatic rings. The structure of $\mathbf{3 c}$ was unambiguously confirmed by X-rays crystallography. Compounds $\mathbf{3 a}, \mathbf{3 e}$ and $\mathbf{3 g}$ also afforded single-crystals whose $\mathrm{X}$-rays structures are shown in Figure 1.

During the investigation on the reactivity of butenolide 1 with benzaldehyde in Knoevenagel condition, compound 3a and $\mathbf{5}$ were obtained, and the structure of the later
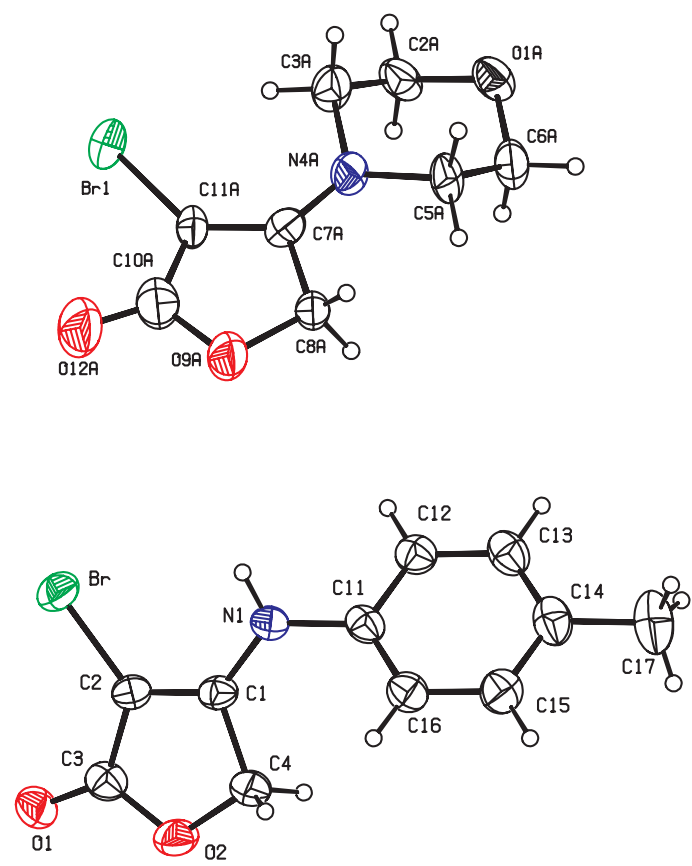

was corroborated by X-rays crystallography, as shown in Figure 2. Mechanistically, the formation of $\mathbf{3 a}$ follows the same addition-elimination pathway above mentioned, and the formation of $\mathbf{5}$ represents a three component reaction. In a control experiment, tetronamide $\mathbf{3} \mathbf{a}$ and benzaldehyde were left in the same Knoevenagel reaction condition, but the reagents were quantitatively recovered. Additionally, butenolide 1 and benzaldehyde were tentatively reacted in Knoevenagel condition with other no nucleophilic bases,
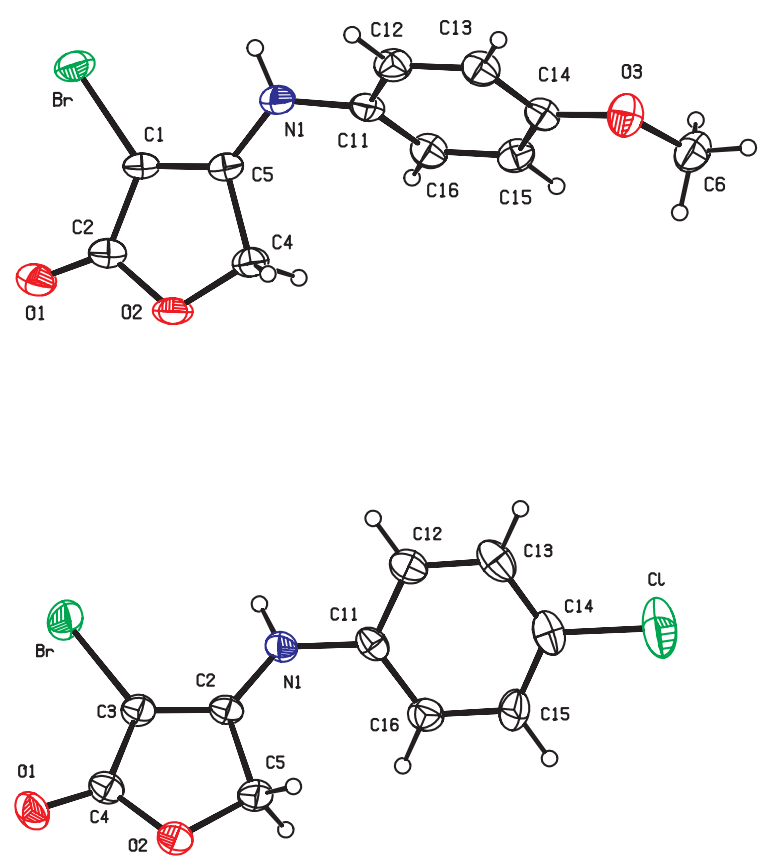

Figure 1. Ortep ${ }^{12}$ representations of $\mathbf{3 a}$ (top left), $\mathbf{3 c}$ (bottom left), $\mathbf{3 e}$ (top right), and $\mathbf{3 g}$ (bottom right). Displacement ellipsoids are drawn at the $30 \%$ probability level and $\mathrm{H}$ atoms are shown as spheres of arbitrary radius.

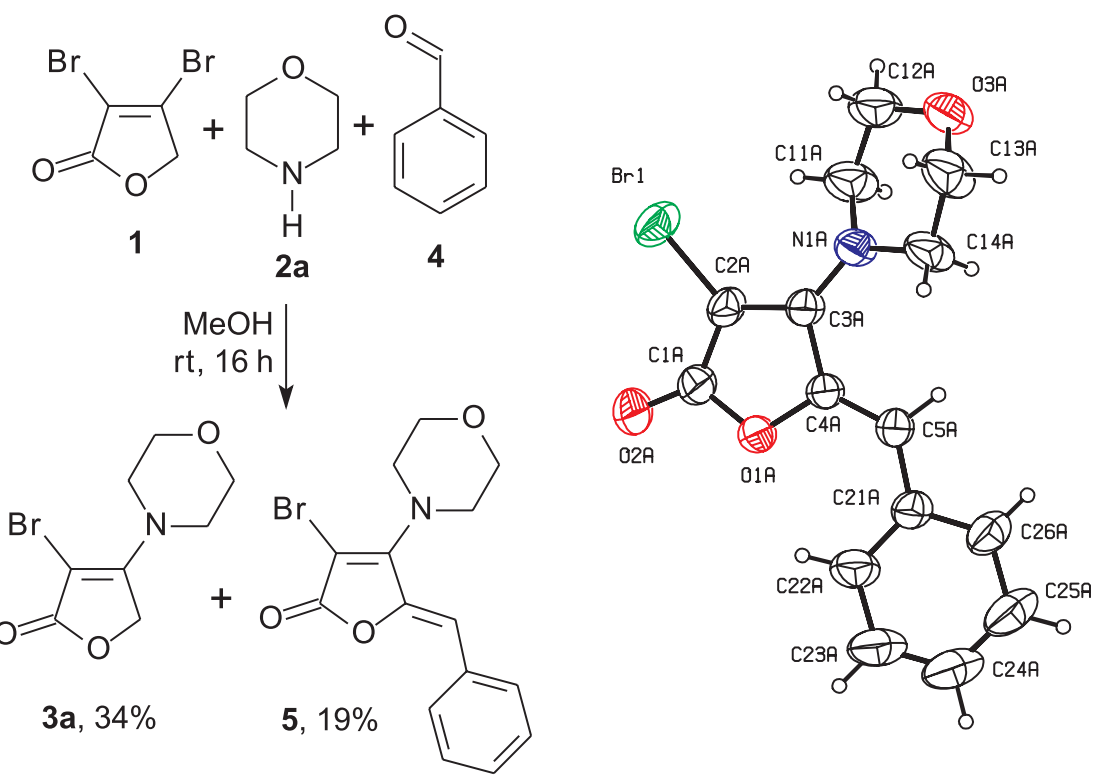

Figure 2. Tricomponent reaction and Ortep ${ }^{12}$ representation of 5. Displacement ellipsoids are drawn at the $30 \%$ probability level and $\mathrm{H}$ atoms are shown as spheres of arbitrary radius. 
being the reagents recovered or the decomposition of $\mathbf{1}$ observed. These facts ruled out $\mathbf{3 a}$ as the intermediate in the formation of $\mathbf{5}$, suggesting a homoaldol reaction of $\mathbf{1}$ and $\mathbf{4}$ followed by an addition-elimination and a last step of water elimination to afford $\mathbf{5}$.

In contrast of the amines' behavior with butenolide $\mathbf{1}$, which afforded tetronamides $\mathbf{3} \mathbf{a}$-j in good yields, no reaction was observed with phenol. To gain more insight into the potential of 3-bromotetronamides $\mathbf{3 a} \mathbf{a} \mathbf{j}$ as building block, compound $\mathbf{3 b}$ was submitted to diverse intramolecular Mizoroki-Heck reaction conditions, but the substrate was recovered unchanged. The unique observed transformation under these condition was the debromination of the butenolide ring when dioxane was employed as solvent with compounds $\mathbf{3 b}, \mathbf{e}$, affording the two known tetronamides $\mathbf{6 a}, \mathbf{b},{ }^{13}$ which represents a palladium catalyzed dehalogenation without a formal hydride donor font, Scheme 2. A proposed mechanism of the palladium-catalyzed dehalogenation reaction is indicated in Figure 3, which was inspired in a previously described formal hydride-free donor one, ${ }^{14}$ where DMF was employed as solvent and act as a hydride source. Thus, the intermediate formed by the insertion of

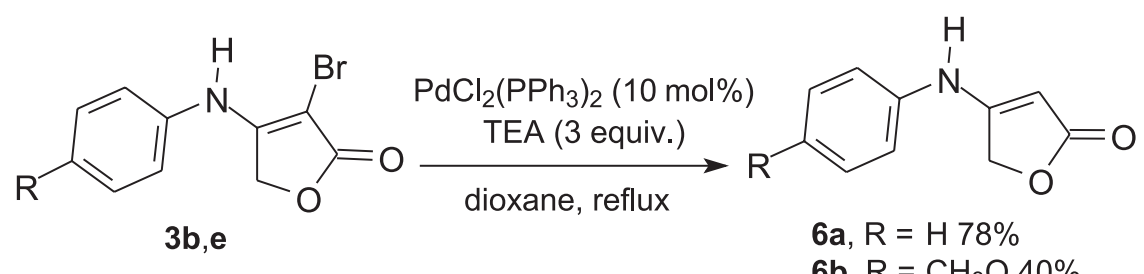

Scheme 2.

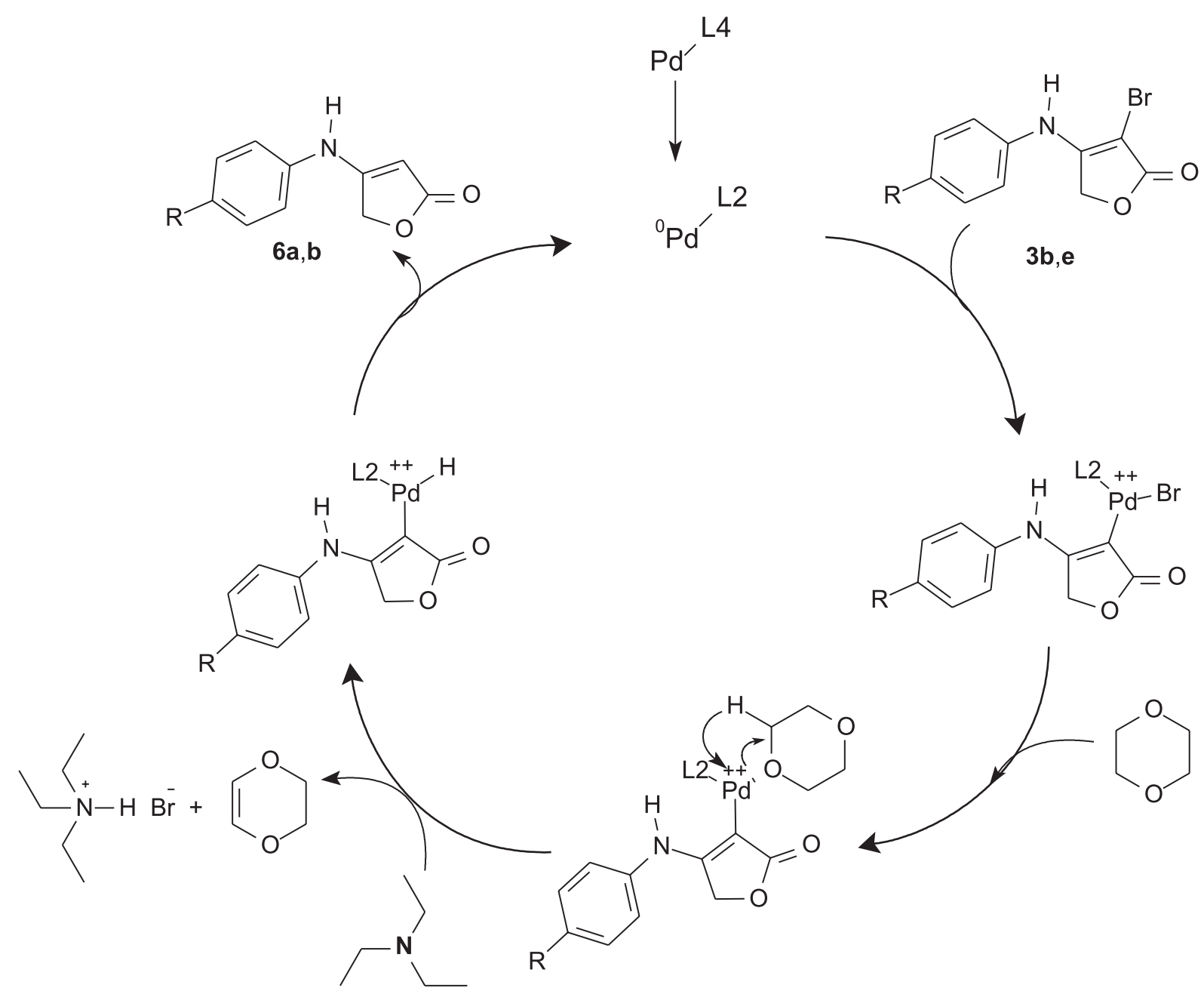

Figure 3. Proposed mechanism of Pd-catalyzed dehalogenation. 
palladium (0) into the $\mathrm{C}$-Br bond would react with dioxane in the presence of triethylamine to yield the specie that should suffer a beta-H elimination, followed by reductive elimination of $\mathrm{Pd}^{0}$ from the resulting hydridopalladium complex to give C-H, Figure 3.

In conclusion, we developed a practical synthesis of 3-bromotetronamides in good yields, describing for the first time that 3,4-dibromofuran-2(5H)-one $\mathbf{1}$ can be conveniently employed as electrophile in reactions with aromatic amines, amplifying the scope of such transformation. ${ }^{11}$ Efforts are underway on the application of these $\alpha$-bromoenaminones in the synthesis of natural and unnatural bioactive compounds.

\section{Experimental}

Melting points were determined on a Microquímica MQAPF 301 hot plate apparatus and are uncorrected. Infrared spectra were recorded as $\mathrm{KBr}$ discs on a FT-IR BOMEM MB100 instrument. NMR spectra were obtained for ${ }^{1} \mathrm{H}$ at $300 \mathrm{MHz}$ and for ${ }^{13} \mathrm{C}$ at $75 \mathrm{MHz}$ using a Varian Gemini 300 spectrometer. Chemical shifts are reported in ppm units downfield from reference (internal TMS).

\section{General synthetic condition A}

To a solution of $1.0 \mathrm{mmol}$ of $\mathbf{1}$ in $10 \mathrm{~mL}$ of $\mathrm{CH}_{3} \mathrm{OH}$ was added $2.0 \mathrm{mmol}$ of amine $\mathbf{2}$. The solution was left at room temperature at the indicated time in Table 1. After this time, the solvent was evaporated and $20 \mathrm{~mL}$ of $\mathrm{CHCl}_{3}$ was added, extracted with water $(3 \times 5 \mathrm{~mL})$, and the organic layer was dried over anhydrous $\mathrm{Na}_{2} \mathrm{SO}_{4}$, filtrated and the solvent evaporated. The crude residue was recrystallized from $\mathrm{CHCl}_{3}$ /hexane affording a solid.

\section{General synthetic condition B}

To a solution of $1.0 \mathrm{mmol}$ of $\mathbf{1}$ in $10 \mathrm{~mL}$ of $\mathrm{CH}_{3} \mathrm{OH}$ were added $1.0 \mathrm{mmol}$ of $\mathrm{NaHCO}_{3}$ and $1.0 \mathrm{mmol}$ of amine 2 . The solution was left at room temperature at the indicated time in Table 1. After this time, the solvent was evaporated and $20 \mathrm{~mL}$ of $\mathrm{CHCl}_{3}$ was added, extracted with water $(3 \times 5 \mathrm{~mL})$, and the organic layer was dried over anhydrous $\mathrm{Na}_{2} \mathrm{SO}_{4}$, filtrated and the solvent evaporated. The crude residue was recrystallized from $\mathrm{CHCl}_{3}$ /hexane affording a solid.

\section{Synthesis of $\mathbf{3 a}$ and $\mathbf{5}$}

To a solution of $\mathbf{1}(0.613 \mathrm{~g}, 2.54 \mathrm{mmol})$ and benzaldehyde $(0.531 \mathrm{~g}, 5 \mathrm{mmol})$ in $20 \mathrm{~mL}$ of methanol, was added $0.356 \mathrm{~mL}$ of morpholine $(0.349 \mathrm{~g}, 4 \mathrm{mmol})$ under magnetic stirring at room temperature. After $16 \mathrm{~h}$ the solvent was evaporated and the crude residue purificated by column chromatography (hexane:ethyl acetate 4:1), affording $0.162 \mathrm{~g}$ (19\% yield) of $\mathbf{5}$ as a yellow solid, and $0.210 \mathrm{~g}$ (34\% yield) of yellow solid 3a after recrystallization in ethyl acetate.

\section{Compound $\mathbf{3 a}$}

mp 128-129 ${ }^{\circ} \mathrm{C}$; IR (KBr) $v_{\max } / \mathrm{cm}^{-1}: 1766,1029,990$; ${ }^{1} \mathrm{H} \mathrm{NMR}\left(\mathrm{CDCl}_{3}\right) \delta 3.63-3.66(\mathrm{~m}, 4 \mathrm{H}), 3.78-3.81(\mathrm{~m}, 5 \mathrm{H})$, $4.71(\mathrm{~s}, 2 \mathrm{H}) ;{ }^{13} \mathrm{C}$ NMR $\left(\mathrm{CDCl}_{3}\right) \delta 171.41,159.26,72.80$, $67.52,66.17,47.10$.

\section{Compound 5}

mp 149-154 ${ }^{\circ} \mathrm{C}$; IR (KBr) $v_{\max } / \mathrm{cm}^{-1}: 2867,1742,1727$, 1621,$1450 ;{ }^{1} \mathrm{H} \mathrm{NMR}\left(\mathrm{CDCl}_{3}\right) \delta 3.69-3.72(\mathrm{t}, 4 \mathrm{H}, J 9.3 \mathrm{~Hz})$, 3.85-3.88 (t, 4H, J 9.3 Hz), $6.13(\mathrm{~s}, 1 \mathrm{H}), 7.32-7.41(\mathrm{~m}, 3 \mathrm{H})$, 7.71-7.44 (m, $2 \mathrm{H}) ;{ }^{13} \mathrm{C} \mathrm{NMR}\left(\mathrm{CDCl}_{3}\right) \delta 50.85,67.07,85.33$, 111.10, 128.80, 129.18, 130.54, 132.17, 157.11, 165.43.

\section{Synthesis of $\mathbf{6 a}, \boldsymbol{b}$}

A suspension of $\mathbf{3 b}, \mathbf{e}(0.5 \mathrm{mmol}), \mathrm{PdCl}_{2}\left(\mathrm{PPh}_{3}\right)_{2}$ $(0.035 \mathrm{~g}, 0.05 \mathrm{mmol})$ and triethylamine $(0.15 \mathrm{~g}, 1.5 \mathrm{mmol})$ in dry, degassed dioxane was refluxed until total substrate consume (15 and $68 \mathrm{~h}$ for $\mathbf{3 b}$ and $\mathbf{3 e}$, respectively). The solvent was evaporated and the crude residue purificated by column chromatography (ethyl acetate:hexane 7:3).

\section{Compound $\mathbf{6 a}$}

Pale brown solid, mp 201-203 ${ }^{\circ} \mathrm{C}$ (lit. ${ }^{13} 220-221{ }^{\circ} \mathrm{C}$ ); ${ }^{1} \mathrm{H}$ NMR (DMSO-D $\left.{ }_{6}\right) \delta 4.92$ (s, 2H), 5.30 (s, 1H), 7.05 (t, 1H, J $7 \mathrm{~Hz}) ; 7.19(\mathrm{~d}, 2 \mathrm{H}, J 7 \mathrm{~Hz}), 7.38(\mathrm{t}, 2 \mathrm{H}, J 7 \mathrm{~Hz})$, $9.68(\mathrm{~s}, 1 \mathrm{H})$.

\section{Compound $\boldsymbol{6} \boldsymbol{b}$}

Pale brown solid; ${ }^{1} \mathrm{H}$ NMR $\left(\mathrm{CDCl}_{3}\right) \delta 4.94(\mathrm{~s}, 2 \mathrm{H})$, 5.19 (s, 1H), 7.05 (d, 2H, J $10 \mathrm{~Hz}) ; 7.21(\mathrm{~d}, 2 \mathrm{H}, J 10 \mathrm{~Hz})$, $9.60(\mathrm{~s}, 1 \mathrm{H})$.

$X$-ray analysis

Single-crystals of the compounds $\mathbf{3 a}, \mathbf{3} \mathbf{c}$ and $\mathbf{3 g}$ were mounted on a Bruker KappaCCD diffractometer, using graphite filtered Mo-K $\alpha$, single-crystals the compounds 3e and $\mathbf{5}$ were mounted on an Enraf-Nonius CAD-4 diffractometer, ${ }^{15}$ using graphite filtered $\mathrm{Cu}-\mathrm{K} \alpha$ radiation, all using room temperature. The structure solutions were obtained by Direct Methods using ShelxS97. ${ }^{16}$ Non hydrogen atoms were refined with anisotropic displacement parameters and hydrogen atoms were refined isotropic with 
riding constraints to their parent atoms using ShelxL97. ${ }^{16}$ Refinement using Full-matrix least-squares on $\mathrm{F}^{2}$.

\section{Supplementary Information}

CCDC 767789 (compound 5), CCDC 767791 (3g), CCDC 767790 (3e), CCDC 643308 (3c) and CCDC 643307 (3a) contains the supplementary crystallographic data for this paper. It can be obtained free of charge via www.ccdc.cam.ac.uk/data_request/cif, or by emailing data_request@ccdc.cam.ac.uk, or by contacting The Cambridge Crystallographic Data Centre, 12, Union Road, Cambridge CB2 1EZ, UK; fax: +44 1223336033. Supplementary data is available free of charge at http://jbcs.sbq.org.br, as PDF file.

\section{Acknowledgments}

We acknowledge the financial support of Conselho Nacional de Desenvolvimento Científico e Tecnológico/ CNPq, Fundação de Amparo à Pesquisa do Estado da Bahia/FAPESB, and IFSC/USP and IF/UFF for the access to the KappaCCD. We also thank CNPQ for fellowship to C. C. O., and research fellowship to S. C.

\section{References}

1. Madec, D.; Mingoia, F.; Prestat, G.; Poli, G.; Synlett 2008, 1475; Hehn, J. P.; Gamba-Sánchez, D.; Kemmler, M.; Fleck, M.; Basler, B.; Bach, T.; Synthesis 2010, 2308; Calvo, L.; GonzálezOrtega, A.; Navarro, R.; Pérez, M.; Sañudo, M. C.; Synthesis 2005, 3152; Fariña, F.; Martín, M. V.; Sánchez, F.; Maestro, M. C.; Martín, R.; Synthesis 1983, 397; Pévet, I.; Meyer, C.; Cossy, J.; Synthesis 2003, 663; Tanoury, G. J.; Chen, M.; Dong, Y.; Forslund, R. E.; Magdziak, D.; Org. Lett. 2008, 10, 185. For a recent review see: Barbosa, L. C. A.; Teixeira, R. R.; Pinheiro, P. F.; Maltha; C. R. A.; Demuner, A. J.; Quim. Nova 2010, 33, 1163.

2. Kim, J. M.; Na, J. E.; Kim, J. N.; Tetrahedron Lett. 2003, 44, 6317; Campos, P. J.; Arranz, J.; Rodriguez, M. A.; Tetrahedron Lett. 1997, 38, 8397; Zhou, L.-H.; Yu, X.-Q.; Pu, L.; J. Org. Chem. 2009, 74, 2013; Matsuo, K.; Ishida, S.; Takuno, Y.; Chem. Pharm. Bull. 1994, 42, 1149.

3. Reviews: Lue, P.; Greenhill, J. V. In Advances in Heterocyclic Chemistry, Vol. 67; Katritzky, A. R., ed.; Academic Press: New York, 1997, p. 207; Kuckländer, V. In The Chemistry of Enamines, Part 1; Rappoport, Z., ed.; John Wiley \& Sons: New York, 1994, p. 525; Elliott, M. C.; Wood, J. L.; Wordingham, S.
V.; Trends Heterocycl. Chem. 2005, 10, 73; Cheng, Y.; Huang, Z. T.; Wang, M.-X.; Curr. Org. Chem. 2004, 8, 325; Ferraz, H. M. C.; Pereira, F. L. C.; Quim. Nova 2004, 27, 89; Negri, G; Kascheres, C; Kascheres, A. J.; J. Heterocyclic. Chem. 2004, 41, 461; Kascheres, C. M.; J. Braz. Chem. Soc. 2003, 14, 945; Elassar, A.-Z. A.; El-Khair, A. A.; Tetrahedron 2003, 59, 8463.

4. Sydorenko, N.; Hsung, R. P.; Vera, E. L.; Org. Lett. 2006, 8, 2611; Sydorenko, N.; Hsung, R. P.; Darwish, O. S.; Hanh, J. M.; Liu, J.; J. Org. Chem. 2004, 69, 6732.

5. Kumler, W. D.; J. Am. Chem. Soc. 1940, 62, 2560; Albers, H.; Mohler, W; Chem. Ber. 1963, 96, 357.

6. Schlessinger, R. H.; Petus, T. R. R.; J. Org. Chem. 1994, 59, 3246; Schlessinger, R.; Bergstrom, C. P.; J. Org. Chem. 1995, 60, 16; Schlessinger, R.; Bergstrom, C. P.; Tetrahedron Lett. 1996, 37, 2133.

7. Cunha, S.; Damasceno, F; Ferrari, J.; Tetrahedron Lett. 2007, 48, 5795; Cunha, S.; Bastos, R. M.; Silva, P. O.; Costa, G. A. N.; Vencato, I., Lariucci, C.; Napolitano, H. B.; Oliveira, C. M. A.; Kato, L.; Silva, C. C.; Menezes, D.; Vannier-Santos, M. A.; Monatsh. Chem. 2007, 138, 111; Cunha S.; Silva, V. C.; Napolitano, H. B.; Lariucci, C.; Vencato, I.; J. Braz. Chem. Soc. 2003, 14, 107; Cunha, S.; Rodovalho, W.; Azevedo, N. R.; Mendonça, M. O.; Lariucci, C.; Vencato, I.; J. Braz Chem. Soc. 2002, 13, 629; Cunha, S.; Kascheres, A.; J. Braz. Chem. Soc. 2001, 12, 481.

8. Taylor, G. A.; Org. Synth. Coll. 1963, 4, 688.

9. Bellina, F.; Rossi, R.; Synthesis 2007, 1887; Bellina, F.; Anselmi, C.; Viel, S.; Mannina, L.; Rossi, R.; Tetrahedron 2001, 57, 9997

10. Bellina, F.; Anselmi, C.; Viel, S.; Mannina, L.; Rossi, R.; Tetrahedron 2003, 59, 9001; Bellina, F.; Anselmi, C.; Viel, S.; Mannina, L.; Rossi, R.; Tetrahedron Lett. 2001, 42, 3851; Bellina, F.; Rossi, R.; Synthesis 2002, 2729; Zhang. J.; Blazecka, P. G.; Belmont, D.; Davidson, J. G.; Org. Lett. 2002, 4, 4559.

11. Ripka, A.; Shapiro, G.; Chesworth, R.; WO 2009158473, 2009.

12. Spek, A.L.; J. Appl. Crystallogr. 2003, 36, 7.

13. Wu, J.; Zhang, L.; Gao, K.; Eur. J. Org. Chem. 2006, 5260.

14. Zawisza, A. M.; Muzart, J.; Tetrahedron Lett. 2007, 48, 6738; Moon, J.; Lee, S; J. Organomet. Chem. 2009, 648, 473.

15. Harms, K.; Wocadlo, S.; XCAD4, University of Marburg: Germany, 1995; Duisenberg, A. J. M.; Hooft, R. W. W., Schreurs, A. M. M.; Kroon, J.; J. Appl. Crystallogr. 2000, 33, 893; EvalCCD (1990-2000); Blessing, R. H.; J. Appl. Crystallogr. 1997, 30, 421.

16. Sheldrick, G. M.; Acta Crystalogr., A 2008, 64, 112.

Submitted: July 22, 2010 Published online: October 26, 2010 


\title{
Synthesis of 3-Bromotetronamides via Amination of 3,4-Dibromofuran-2(5H)-one
}

\author{
Silvio Cunha, ${ }^{*, a, c}$ Caio C. Oliveira ${ }^{a, c}$ and José R. Sabino ${ }^{b}$ \\ anstituto de Química and 'Instituto Nacional de Ciência e Tecnologia - INCT em Energia e \\ Ambiente, Universidade Federal da Bahia, Campus de Ondina, 40170-290 Salvador-BA, Brazil

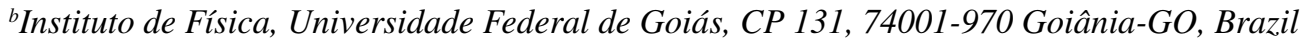

\section{General information}

Melting points were determined on a Microquímica MQAPF 301 hot plate apparatus and are uncorrected. Infrared spectra were recorded as $\mathrm{KBr}$ discs on a FT-IR BOMEM MB100 instrument. NMR spectra were obtained for ${ }^{1} \mathrm{H}$ at $300 \mathrm{MHz}$ and for ${ }^{13} \mathrm{C}$ at $75 \mathrm{MHz}$ using a Varian Gemini 300 spectrometer. Chemical shifts are reported in ppm units downfield from reference (internal TMS).

Table S1. Physical data for compounds 3a-j

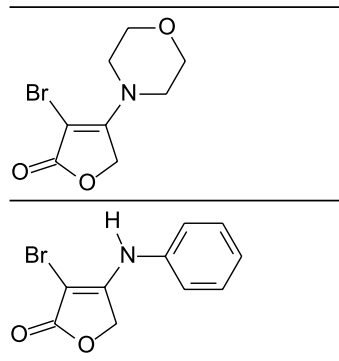

3a: yellow solid, mp 128-129 ${ }^{\circ} \mathrm{C} ; \mathrm{IR}(\mathrm{KBr})$
$v_{\max } / \mathrm{cm}^{-1}: 2360,1766,1029,990 ;{ }^{1} \mathrm{H} \mathrm{NMR}$
$\left(\mathrm{CDCl}_{3}\right) \delta 3.63-3.66(\mathrm{~m}, 4 \mathrm{H}), 3.78-3.81$
$(\mathrm{~m}, 5 \mathrm{H}), 4.71(\mathrm{~s}, 2 \mathrm{H}) ;{ }^{13} \mathrm{C} \mathrm{NMR}\left(\mathrm{CDCl}_{3}\right) \delta$
171.41, 159.26, 72.80, 67.52, 66.17, 47.10.
3b: yellow solid, mp $165-167{ }^{\circ} \mathrm{C} ; \mathrm{IR}(\mathrm{KBr})$
$v_{\max } / \mathrm{cm}^{-1}: 3204,1745,1637,1179 ;{ }^{1} \mathrm{H} \mathrm{NMR}$
$\left(\mathrm{DMSO}-d_{6}\right) 4.97(\mathrm{~s}, 1 \mathrm{H}), 7.09(\mathrm{t}, J 7.2 \mathrm{~Hz}$,
$1 \mathrm{H}), 7.17(\mathrm{~d}, J 7.2 \mathrm{~Hz}, 2 \mathrm{H}) 7.28(\mathrm{t}, J 7.2 \mathrm{~Hz}$,
$2 \mathrm{H}), 9.47(\mathrm{~s}, 1 \mathrm{H}),{ }^{13} \mathrm{C} \mathrm{NMR}\left(\mathrm{CDCl}_{3}\right) \delta$
$170.22,162.16,138.73,129.85,125.74$,
$123.05,74.66,67.99$.

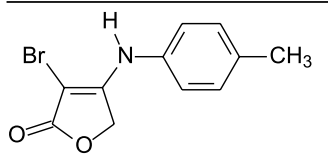

3c: brown solid, mp $146-148{ }^{\circ} \mathrm{C}$; IR $(\mathrm{KBr})$ $v_{\max } / \mathrm{cm}^{-1}: 3229,3072,1730,1627,1049$; ${ }^{1} \mathrm{H}$ NMR $\left(\right.$ DMSO- $\left.d_{6}\right) \delta 2.19(\mathrm{~s}, 3 \mathrm{H}) 4.91(\mathrm{~s}$, 2H), $7.07(\mathrm{~s}, 4 \mathrm{H}), 9.36(\mathrm{~s}, 1 \mathrm{H}) ;{ }^{13} \mathrm{C}$ NMR $\left(\right.$ DMSO- $\left.d_{6}\right) \delta 170.23,162.37,136.10$, 135.22, 130.25, 123.41, 73.98, 67.83, 21.04.<smiles>Cc1ccccc1NC1=C(Br)C(=O)OC1</smiles>

3d: brown solid, mp $166-167{ }^{\circ} \mathrm{C}$; IR (KBr) $v_{\max } / \mathrm{cm}^{-1}: 3227,3042,2933 ; 2836,1713$, 1611, 1036; ' ${ }^{\mathrm{H}}$ NMR (DMSO- $d_{6}$ ) $\delta 2.15$ (s, $3 \mathrm{H}) 4.65(\mathrm{~s}, 2 \mathrm{H}), 7.11-7.22(\mathrm{~m}, 4 \mathrm{H}), 9.16(\mathrm{~s}$, $1 \mathrm{H}$ ); ${ }^{13} \mathrm{C}$ NMR (DMSO- $d_{6}$ ) $\delta 170.69,162.91$, 136.48, 135.23, 131.30, 127.92, 127.36, $127.17,72.40,67.57,18.12$.

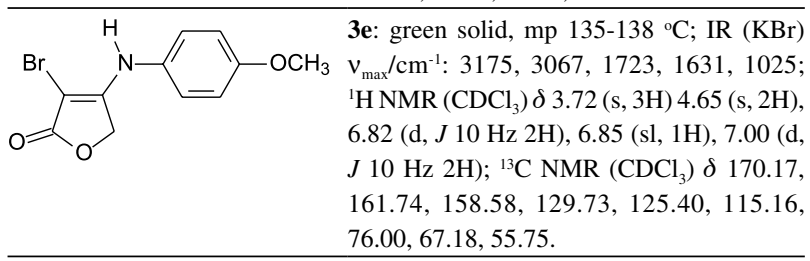
$76.00,67.18,55.75$.

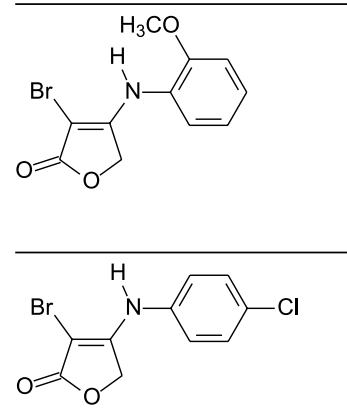

3f: brown solid, mp 100-105 ${ }^{\circ} \mathrm{C}$; IR $(\mathrm{KBr})$ $v_{\max } / \mathrm{cm}^{-1}: 3300,3072,1727,16321050$; ${ }^{1} \mathrm{H}$ NMR $\left(\mathrm{CDCl}_{3}\right) \delta 3.82(\mathrm{~s}, 3 \mathrm{H}) 4.88(\mathrm{~s}$, $2 \mathrm{H}), 6.81-6.88(\mathrm{~m}, 3 \mathrm{H}), 7.03-7.08(\mathrm{~m}, 2 \mathrm{H})$ $7.13(\mathrm{sl}, 1 \mathrm{H}) ;{ }^{13} \mathrm{C}$ NMR $\left(\mathrm{CDCl}_{3}\right) \delta 169.50$, $160.01,150.30,126.95,126.06,121.29$, 119.42, 111.61, 78.41, 67.70, 56.14.

3g: green solid, mp $152-154{ }^{\circ} \mathrm{C}$ (Condition A), or yellow solid, $135-138{ }^{\circ} \mathrm{C}$ (Condition B); IR (KBr) $v_{\max } / \mathrm{cm}^{-1}: 3191,3088,2928$, $1728,1620,1050 ;{ }^{1} \mathrm{H}$ NMR $\left(\mathrm{CDCl}_{3}\right) \delta 6.79$ (s, 1H) $4.86(\mathrm{~s}, 2 \mathrm{H}), 6.97(\mathrm{~d}, J 8.7 \mathrm{~Hz}, 2 \mathrm{H})$, $7.30(\mathrm{~d}, J 8.7 \mathrm{~Hz}, 2 \mathrm{H}), 7.13(\mathrm{~s}, 1 \mathrm{H}) ;{ }^{13} \mathrm{C}$ NMR $\left(\mathrm{DMSO}-d_{6} / \mathrm{CDCl}_{3}\right) \delta 170.17,161.09,137.25$, 130.26, 129.48, 124.44, 75.74, 67.84.

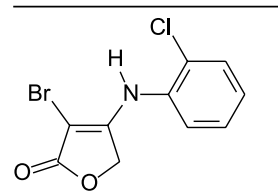

3h: green solid, mp $149-151{ }^{\circ} \mathrm{C}$; IR (KBr) $v_{\max } / \mathrm{cm}^{-1}: 3214,3038,1731,1626,1045$; ${ }^{1} \mathrm{H}$ NMR (DMSO-D6) $\delta 4.82$ (s, 2H), 7.25$7.47(\mathrm{~m}, 3 \mathrm{H}), 7.56-7.59(\mathrm{~m}, 1 \mathrm{H}), 9.53(\mathrm{~s}$, $1 \mathrm{H}) ;{ }^{13} \mathrm{C}$ NMR (DMSO- $d_{6}$ ) $\delta 169.95,161.314$, 134.33, 130.17, 129.88, 129.22, 128.53, 127.87, 73.49, 67.30.
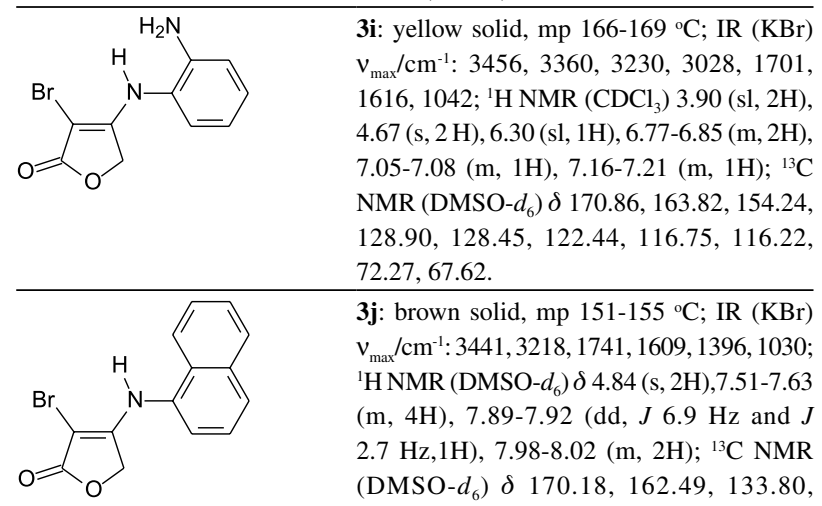

3j: brown solid, $\mathrm{mp} 151-155^{\circ} \mathrm{C}$; IR $(\mathrm{KBr})$ $\mathrm{v}_{\max } / \mathrm{cm}^{-1}: 3441,3218,1741,1609,1396,1030$; ${ }^{1} \mathrm{H}$ NMR (DMSO- $d_{6}$ ) $\delta 4.84$ (s, 2H), 7.51-7.63 (m, 4H), 7.89-7.92 (dd, $J 6.9 \mathrm{~Hz}$ and $J$ $2.7 \mathrm{~Hz}, 1 \mathrm{H}), 7.98-8.02(\mathrm{~m}, 2 \mathrm{H}) ;{ }^{13} \mathrm{C}$ NMR $\left(\right.$ DMSO- $d_{6}$ ) $\delta 170.18,162.49,133.80$, 133.17, 129.43, 128.20, 127.32, 126.70, $126.63,125.55,123.76,122.83,72.65,67.19$. 


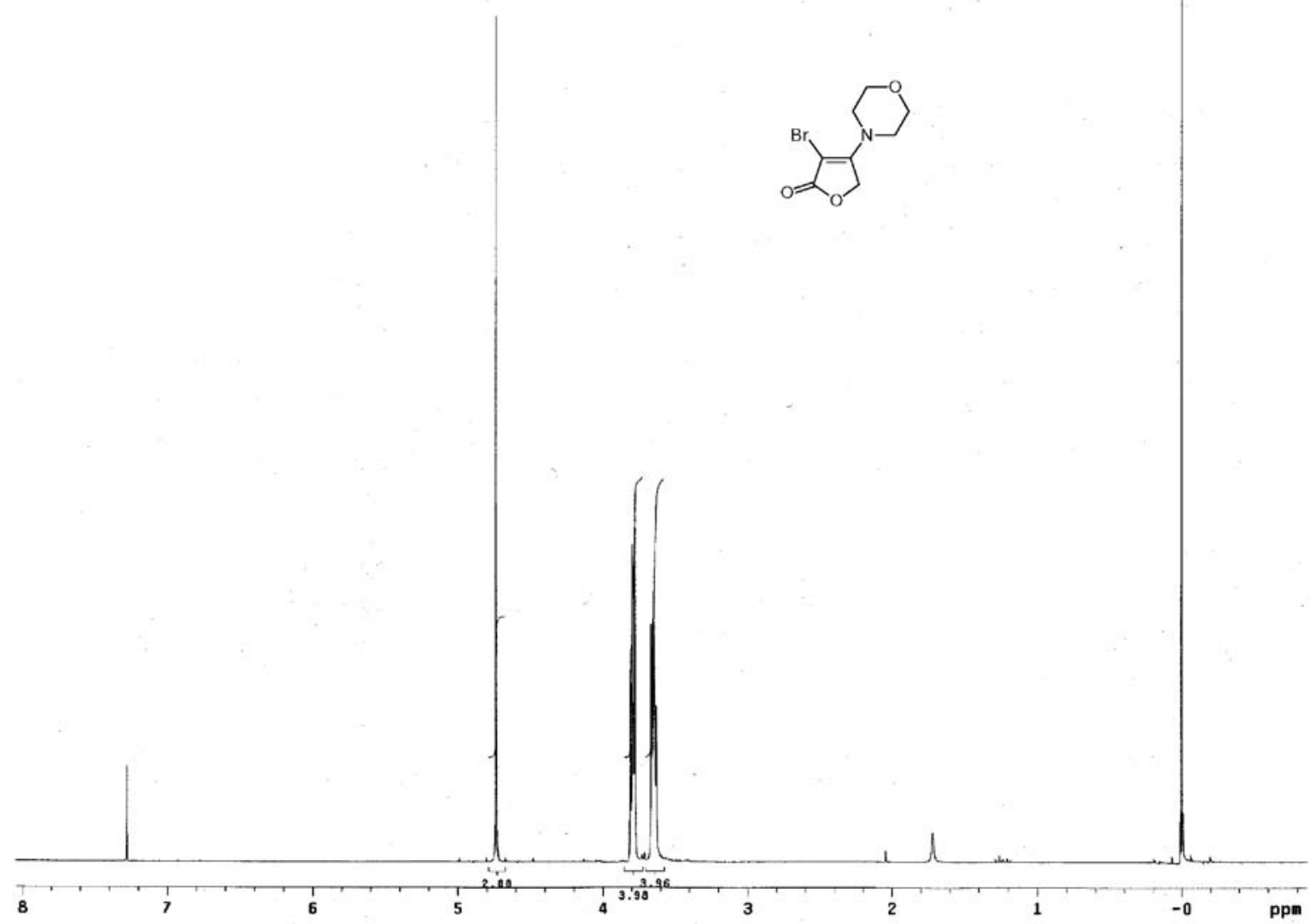

Figure S1. Full ${ }^{1} \mathrm{H}$ NMR spectrum of compound $\mathbf{3 a}\left(\mathrm{CDCl}_{3}\right)$.

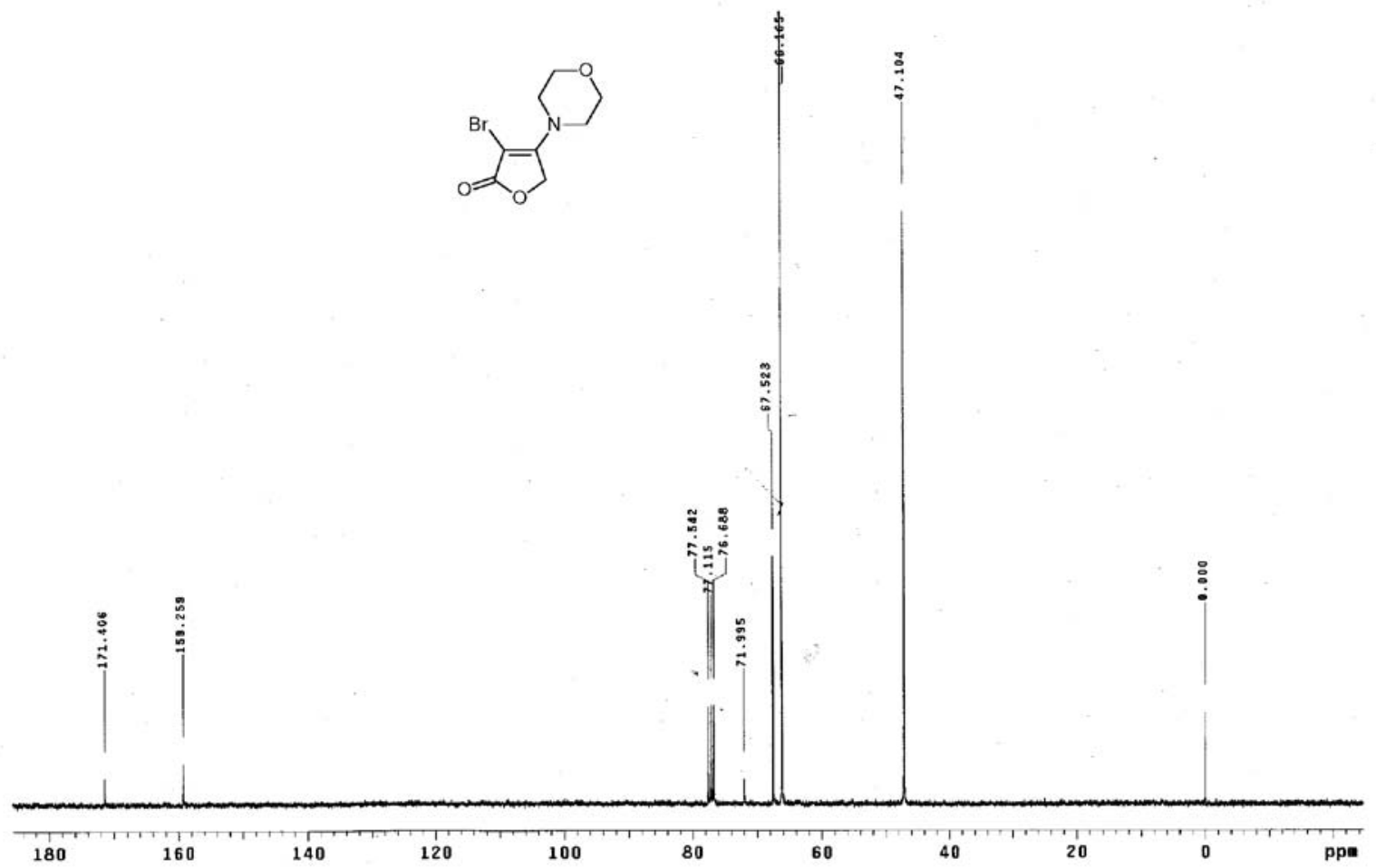

Figure S2. Full ${ }^{13} \mathrm{C}$ NMR spectrum of compound $\mathbf{3 a}\left(\mathrm{CDCl}_{3}\right)$. 


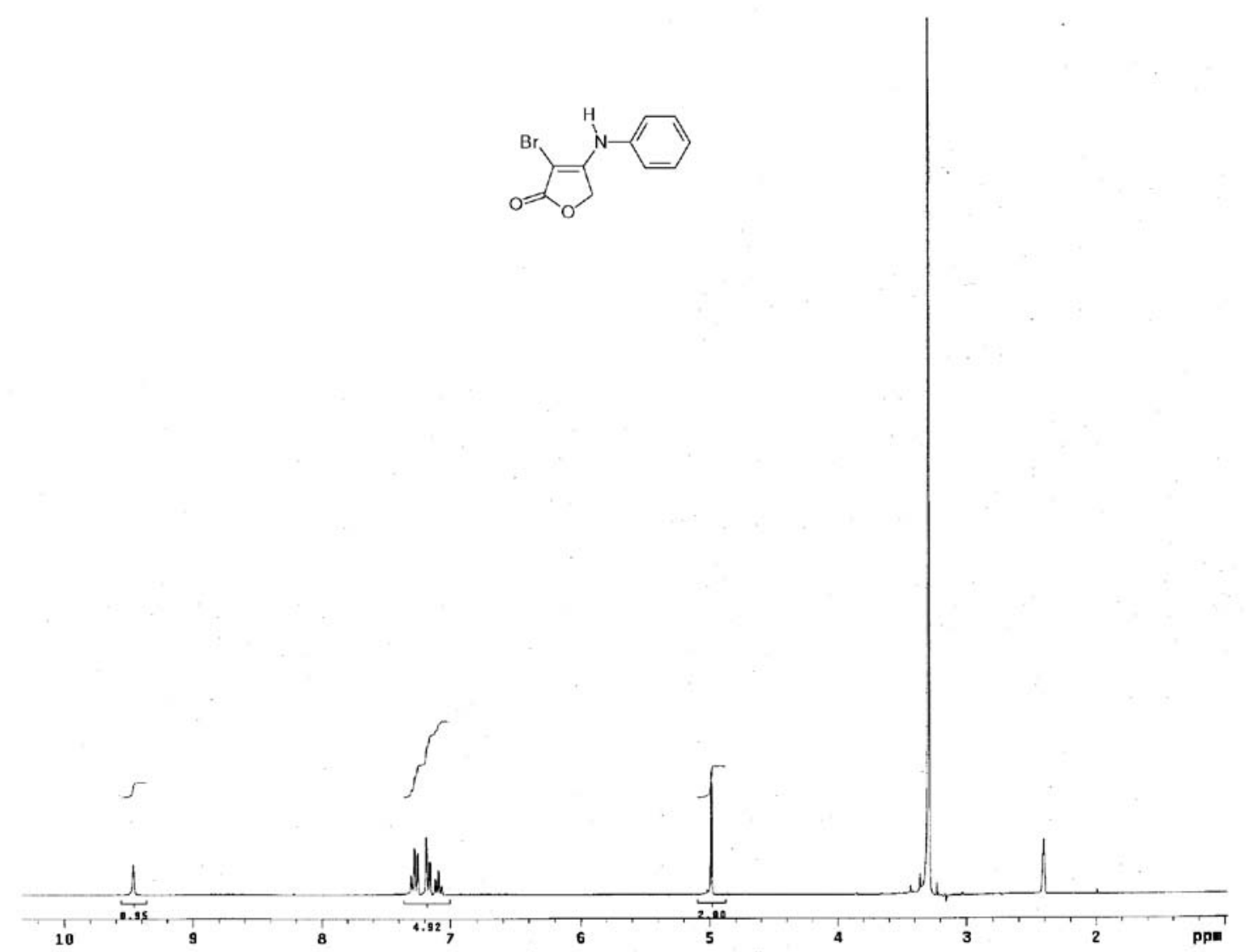

Figure S3. Full ${ }^{1} \mathrm{H}$ NMR spectrum of compound $\mathbf{3 b}\left(\right.$ DMSO- $\left.d_{6}\right)$.

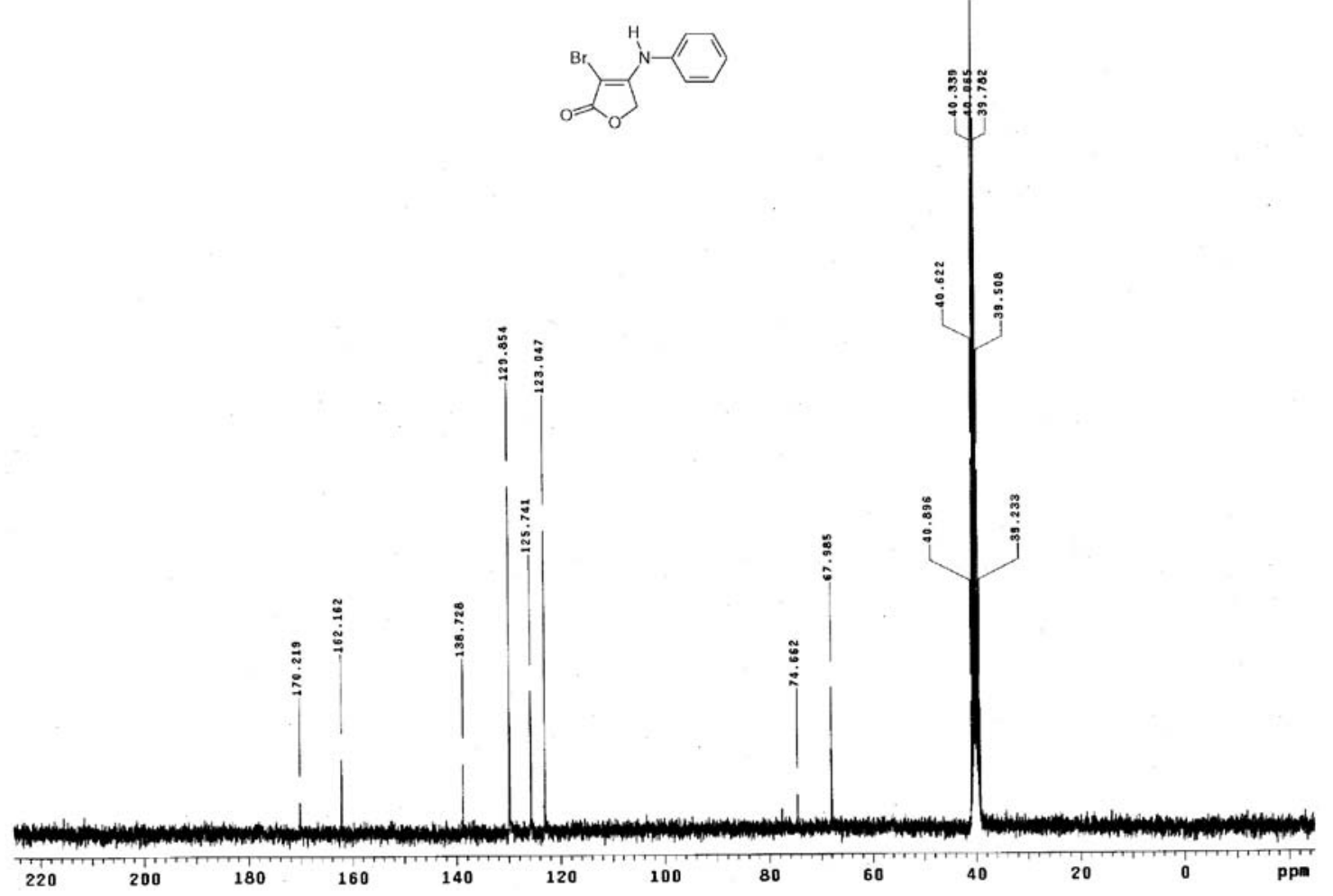

Figure S4. Full ${ }^{13} \mathrm{C}$ NMR spectrum of compound $\mathbf{3 b}$ (DMSO- $d_{6}$ ). 


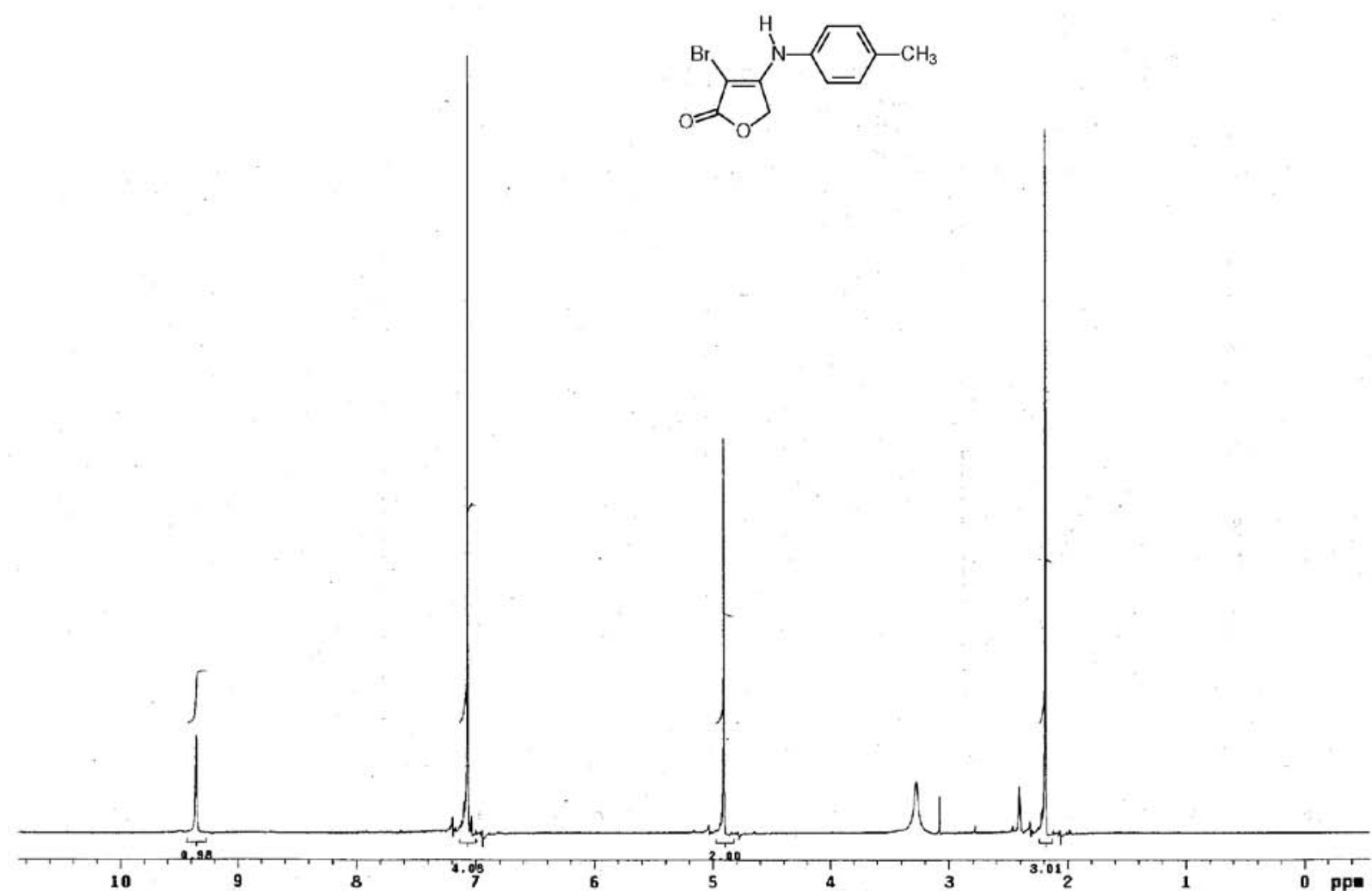

Figure S5. Full ${ }^{1} \mathrm{H}$ NMR spectrum of compound 3c (DMSO- $\left.d_{6}\right)$.

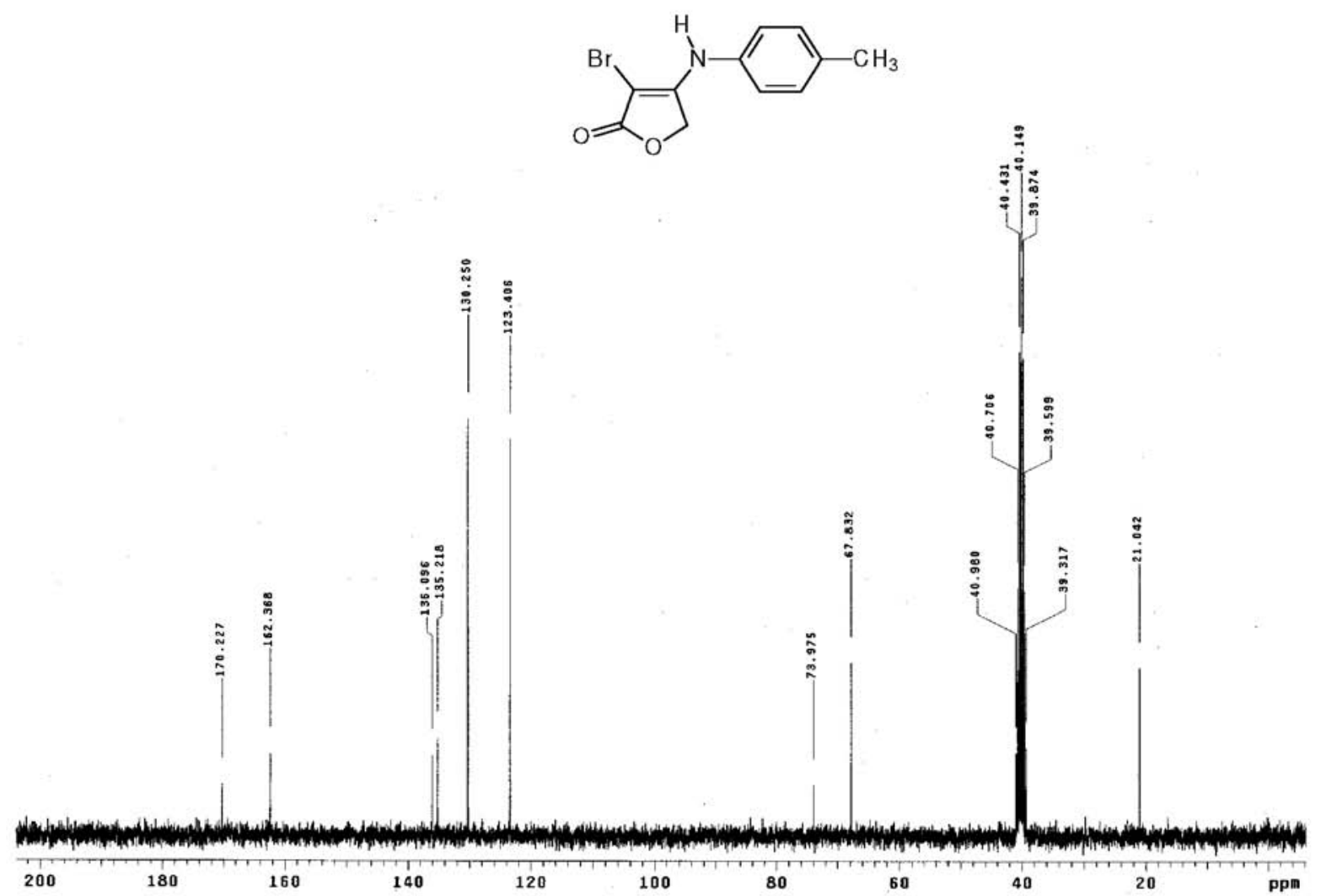

Figure S6. Full ${ }^{13} \mathrm{C}$ NMR spectrum of compound 3c (DMSO- $\left.d_{6}\right)$. 

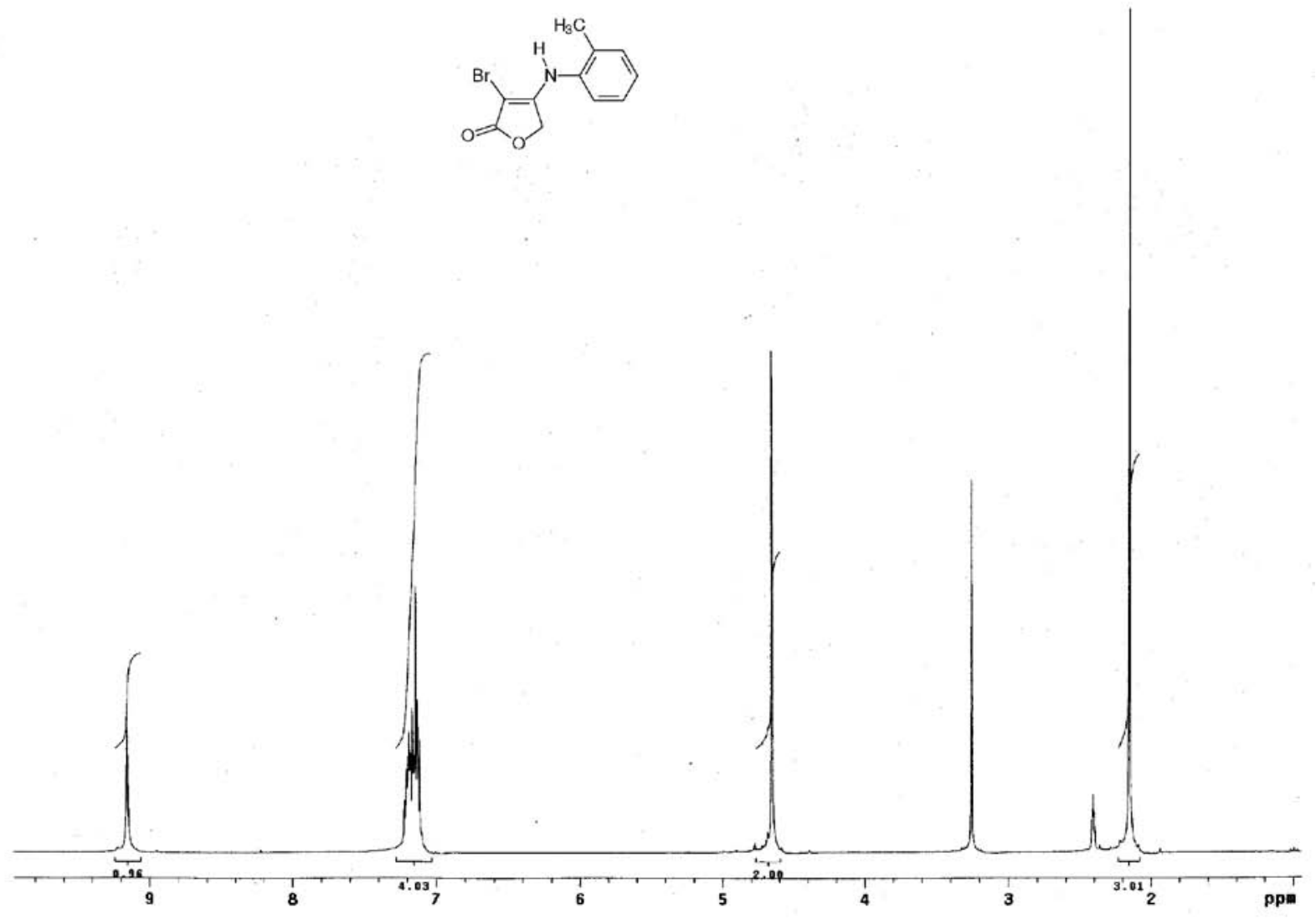

Figure S7.Full ${ }^{1} \mathrm{H}$ NMR spectrum of compound 3d (DMSO- $\left.d_{6}\right)$.

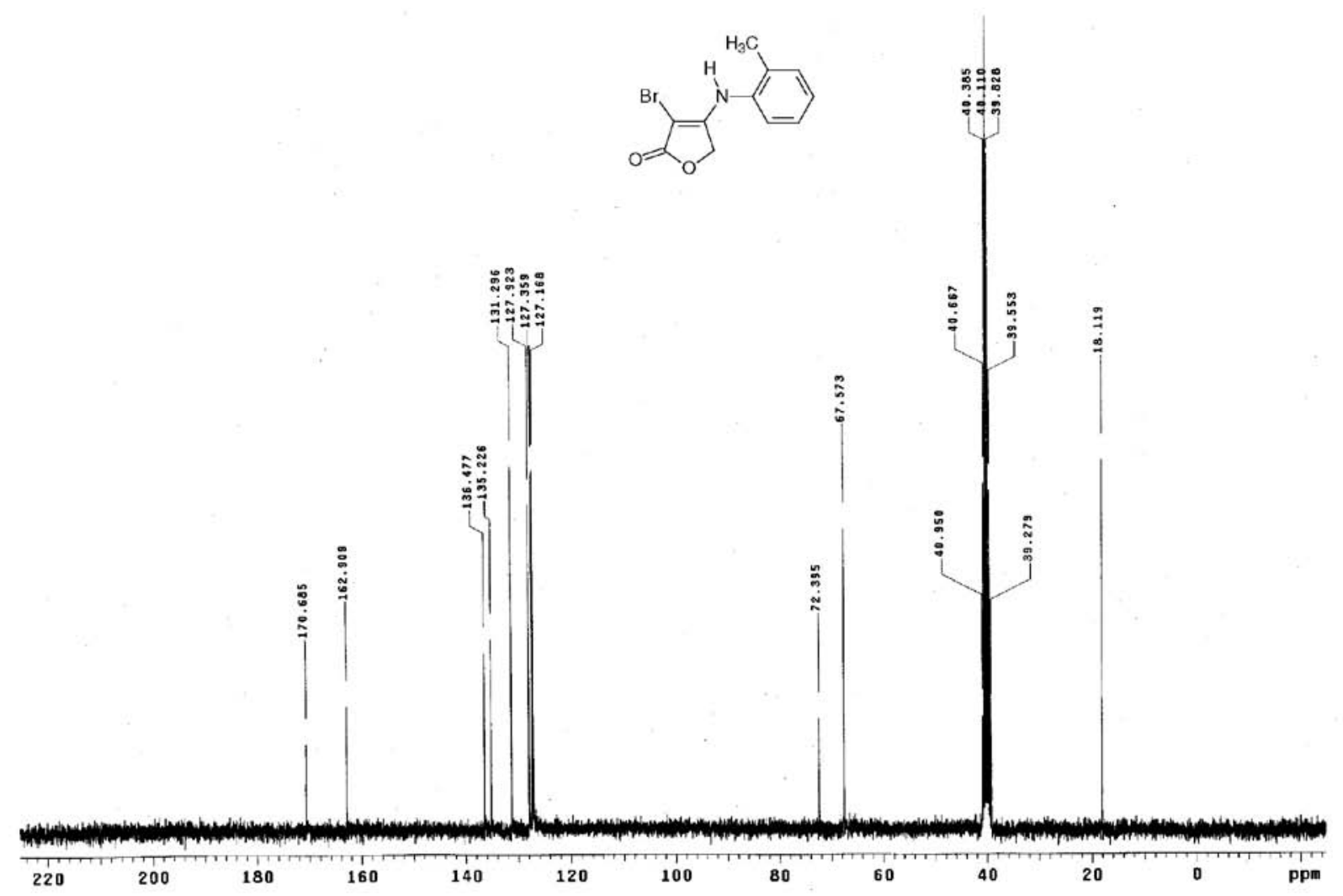

Figure S8. Full ${ }^{13} \mathrm{C}$ NMR spectrum of compound 3d (DMSO- $\left.d_{6}\right)$. 


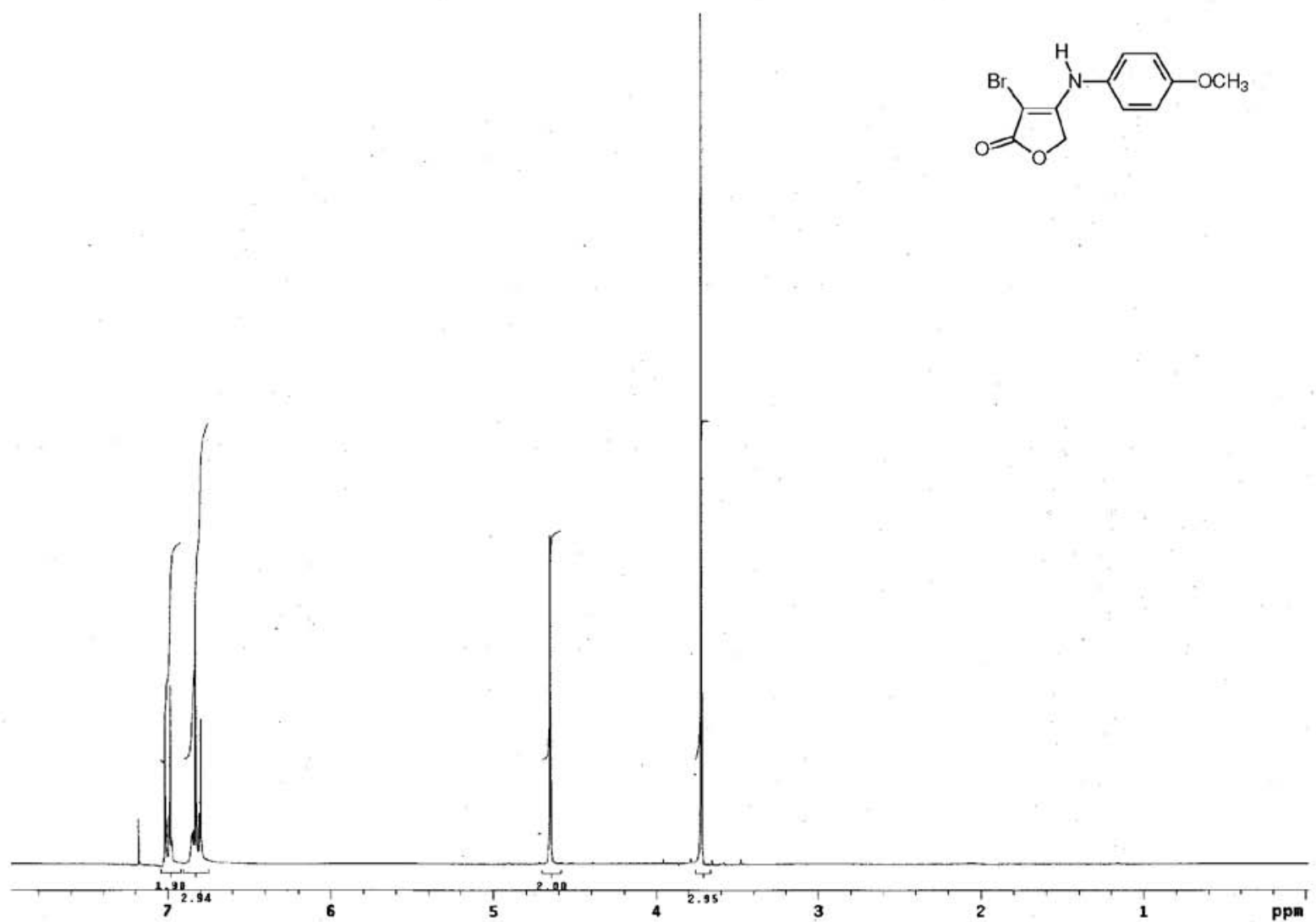

Figure S9. Full ${ }^{1} \mathrm{H}$ NMR spectrum of compound $\mathbf{3 e}\left(\mathrm{CDCl}_{3}\right)$.

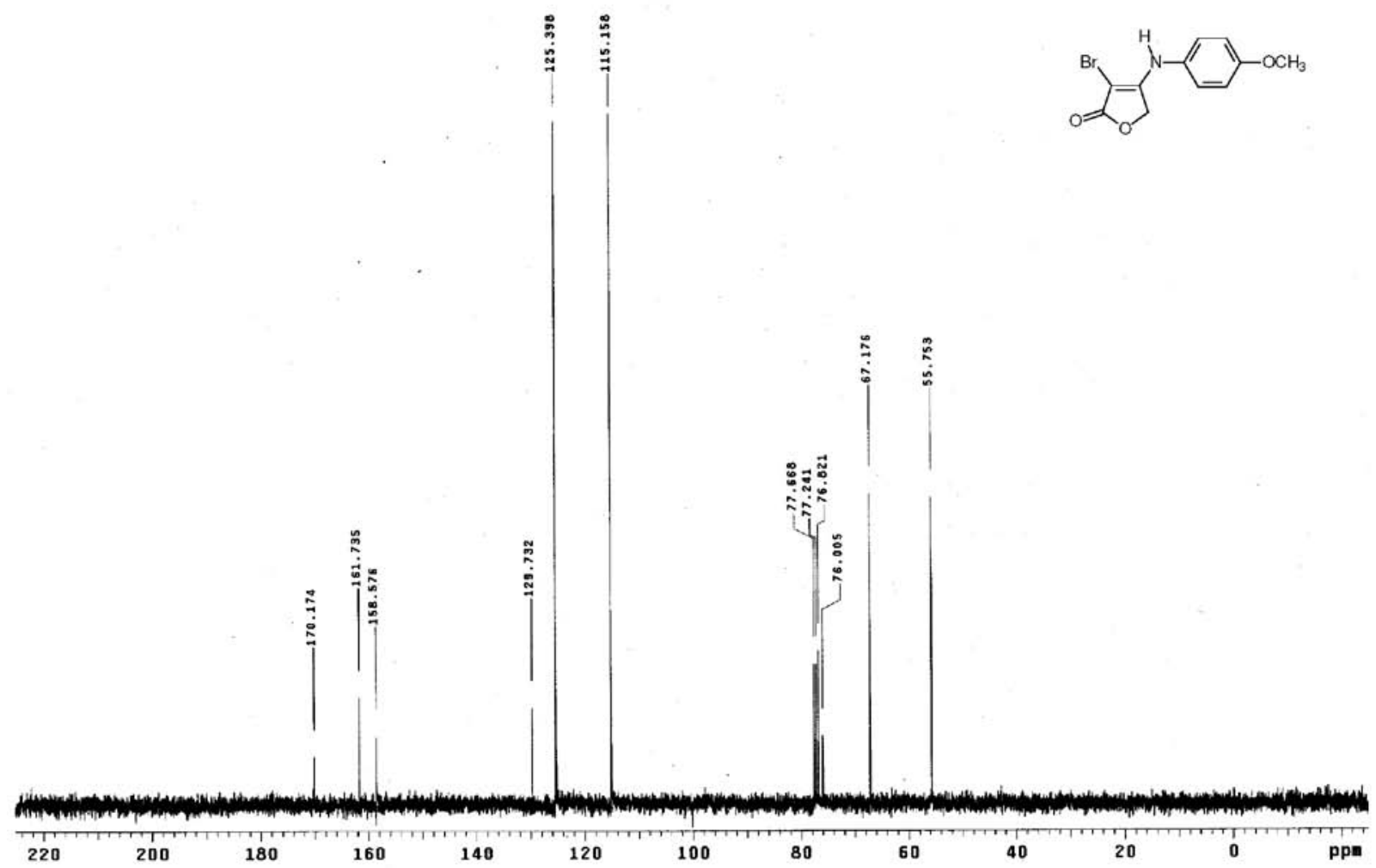

Figure S10. Full ${ }^{13} \mathrm{C}$ NMR spectrum of compound $3 \mathbf{e}\left(\mathrm{CDCl}_{3}\right)$. 


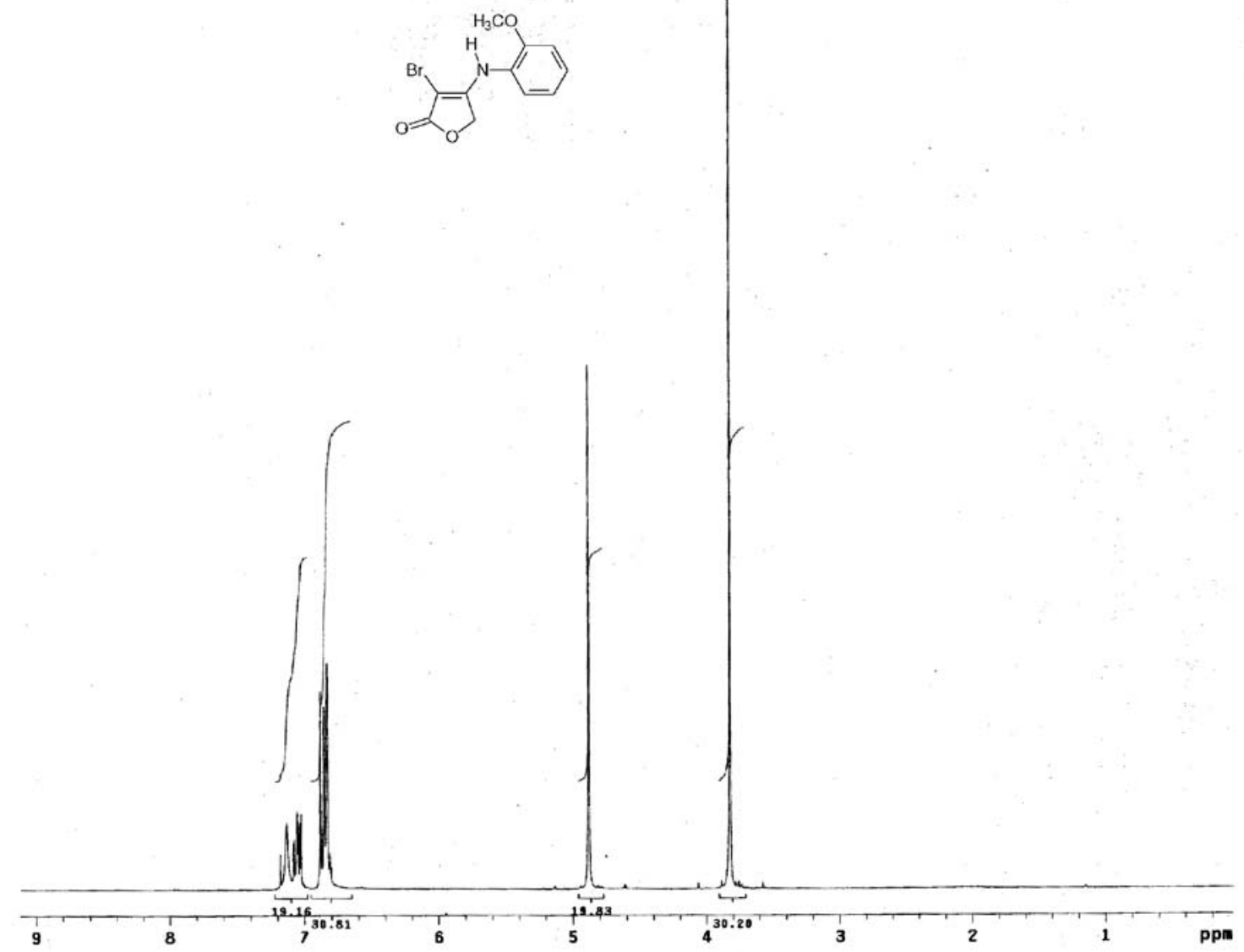

Figure S11. Full ${ }^{1} \mathrm{H}$ NMR spectrum of compound $\mathbf{3 f}\left(\mathrm{CDCl}_{3}\right)$.

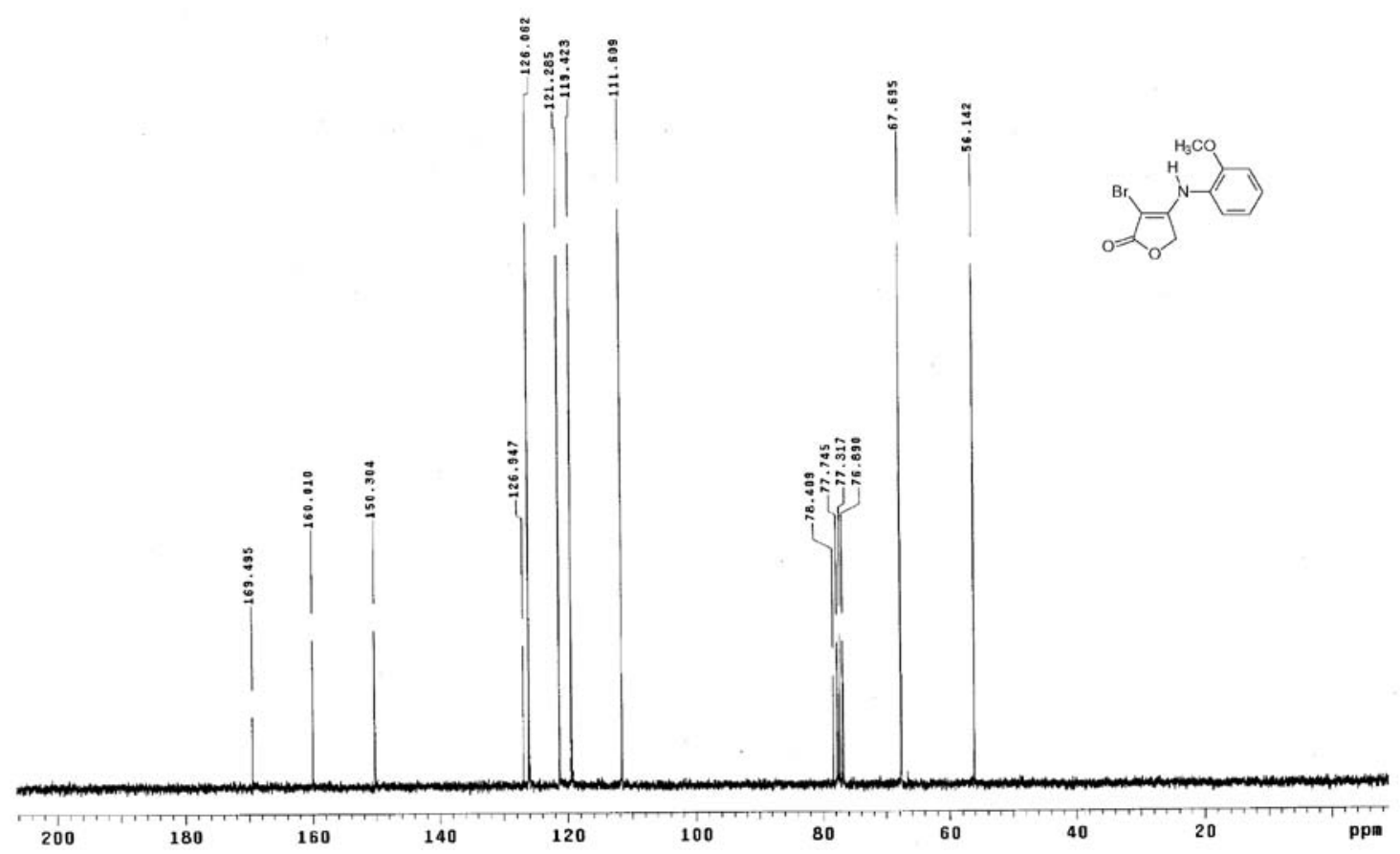

Figure S12. Full ${ }^{13} \mathrm{C}$ NMR spectrum of compound $\mathbf{3 f}\left(\mathrm{CDCl}_{3}\right)$. 


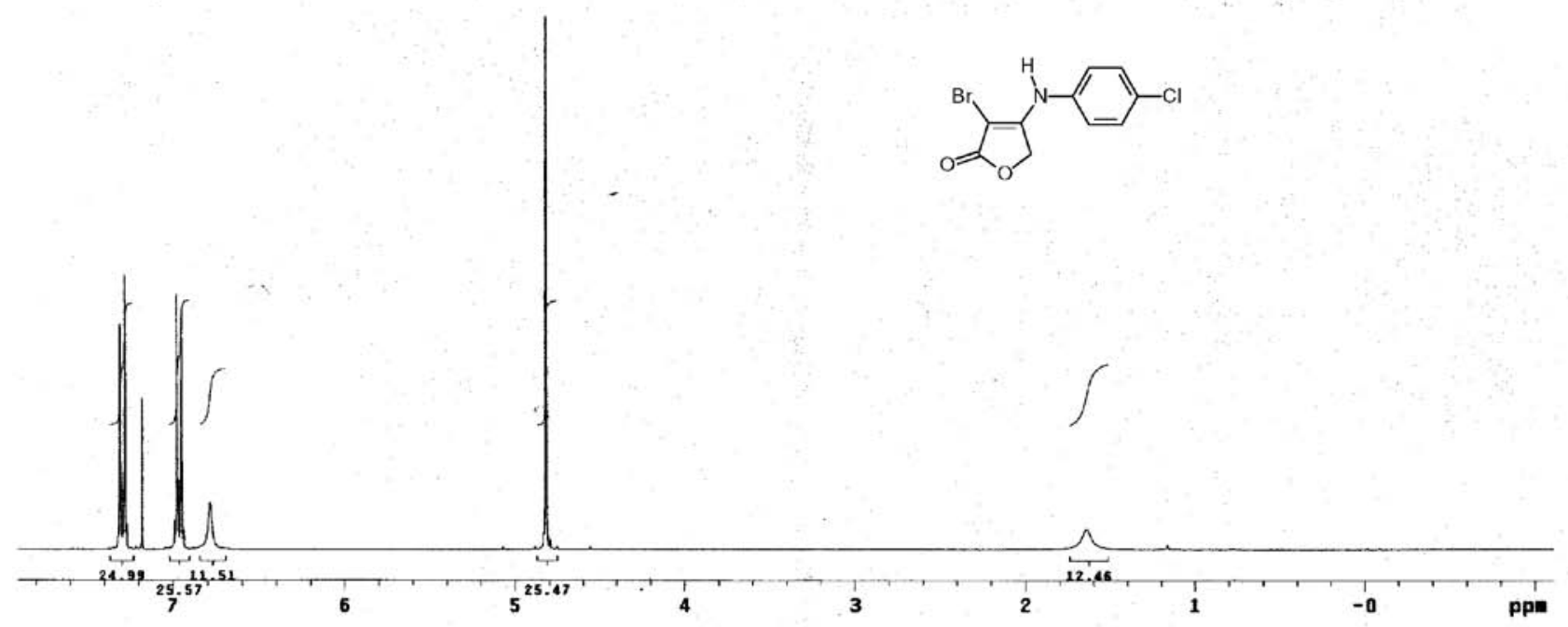

Figure S13. Full ${ }^{1} \mathrm{H}$ NMR spectrum of compound $3 \mathrm{~g}\left(\mathrm{CDCl}_{3}\right)$.

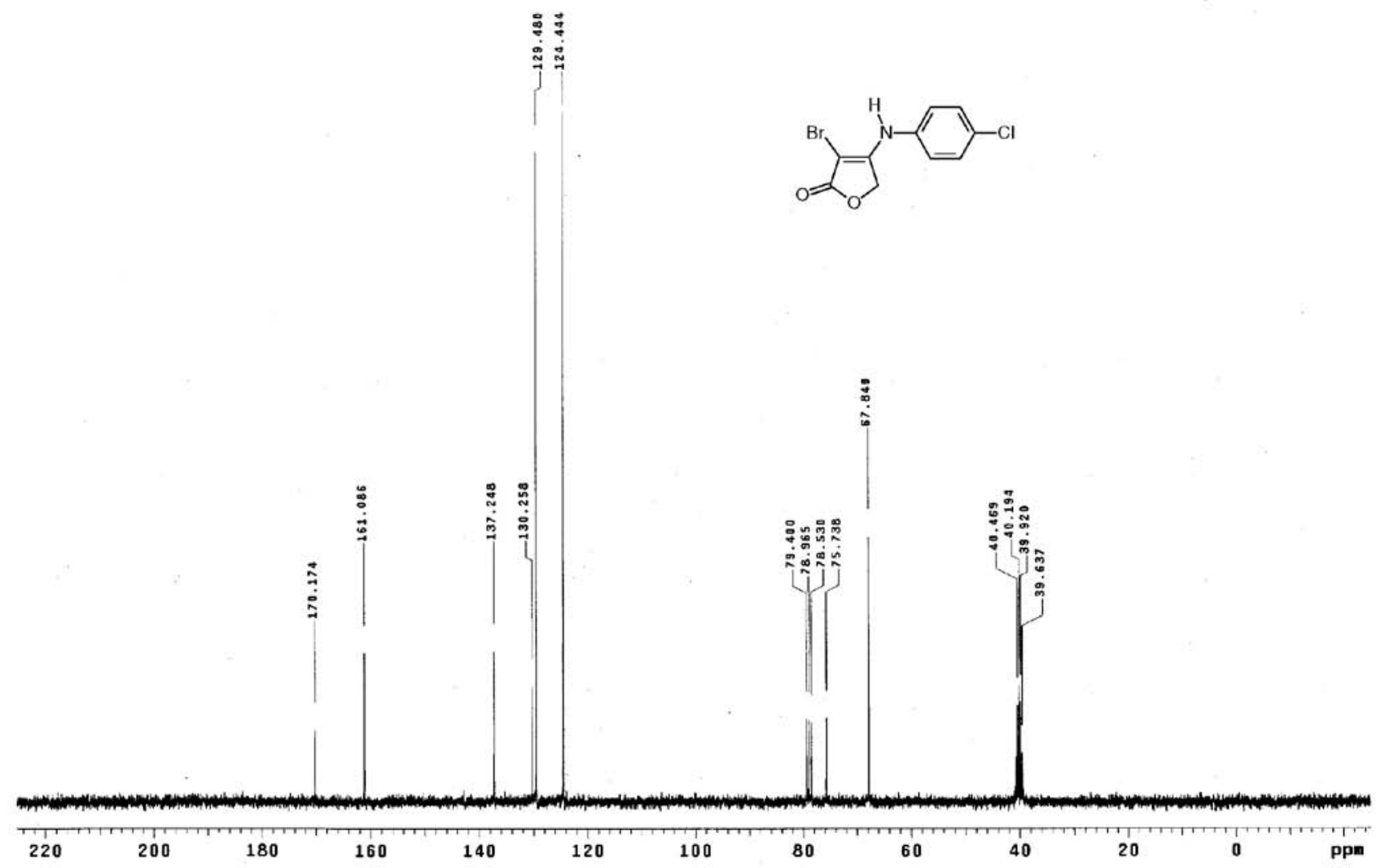

Figure S14. Full ${ }^{13} \mathrm{C}$ NMR spectrum of compound $3 \mathrm{~g}\left(\mathrm{CDCl}_{3} / \mathrm{DMSO}-d_{6}\right)$. 


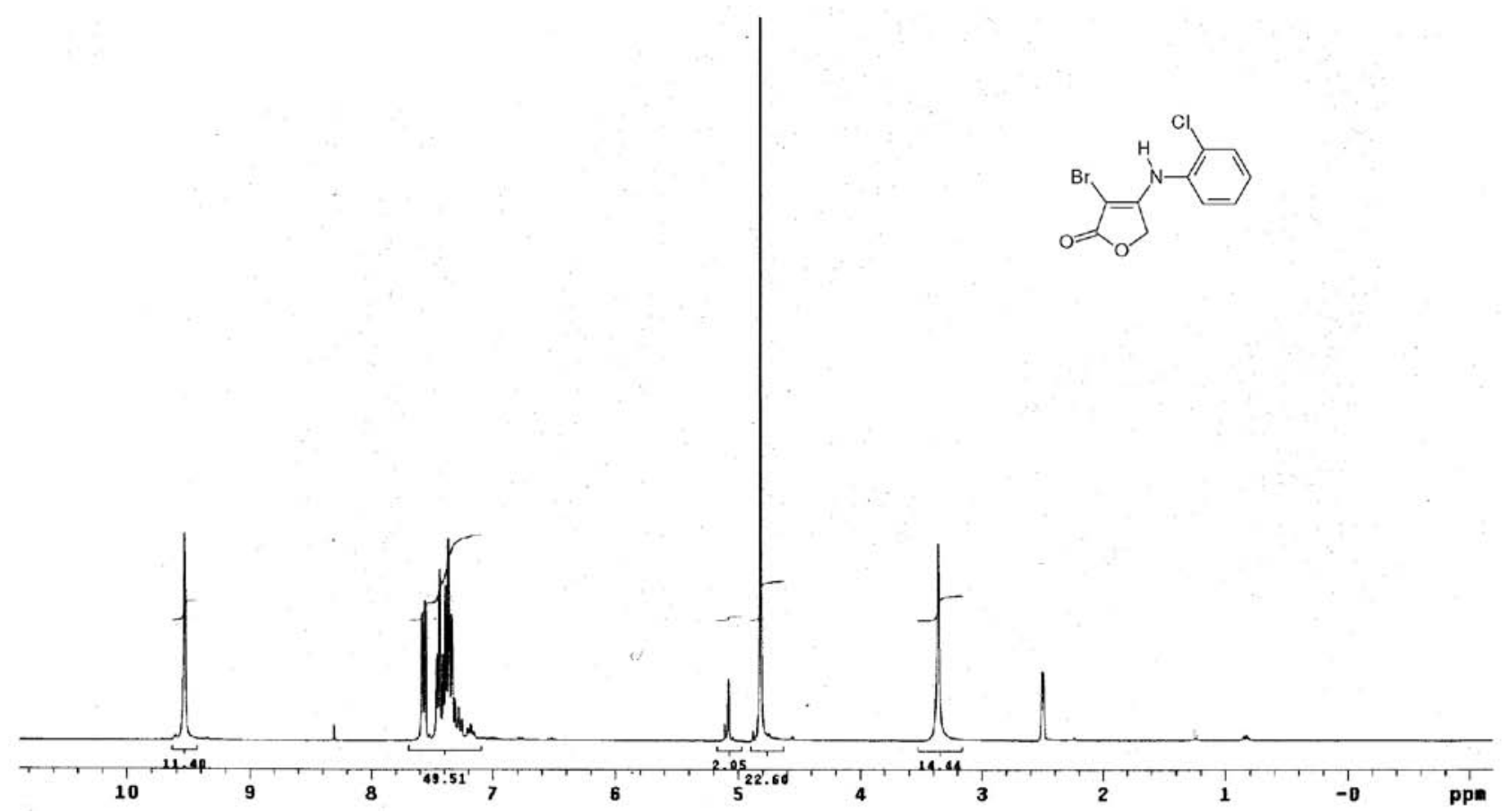

Figure S15. Full ${ }^{1} \mathrm{H}$ NMR spectrum of compound $\mathbf{3 h}\left(\mathrm{CDCl}_{3}\right)$.

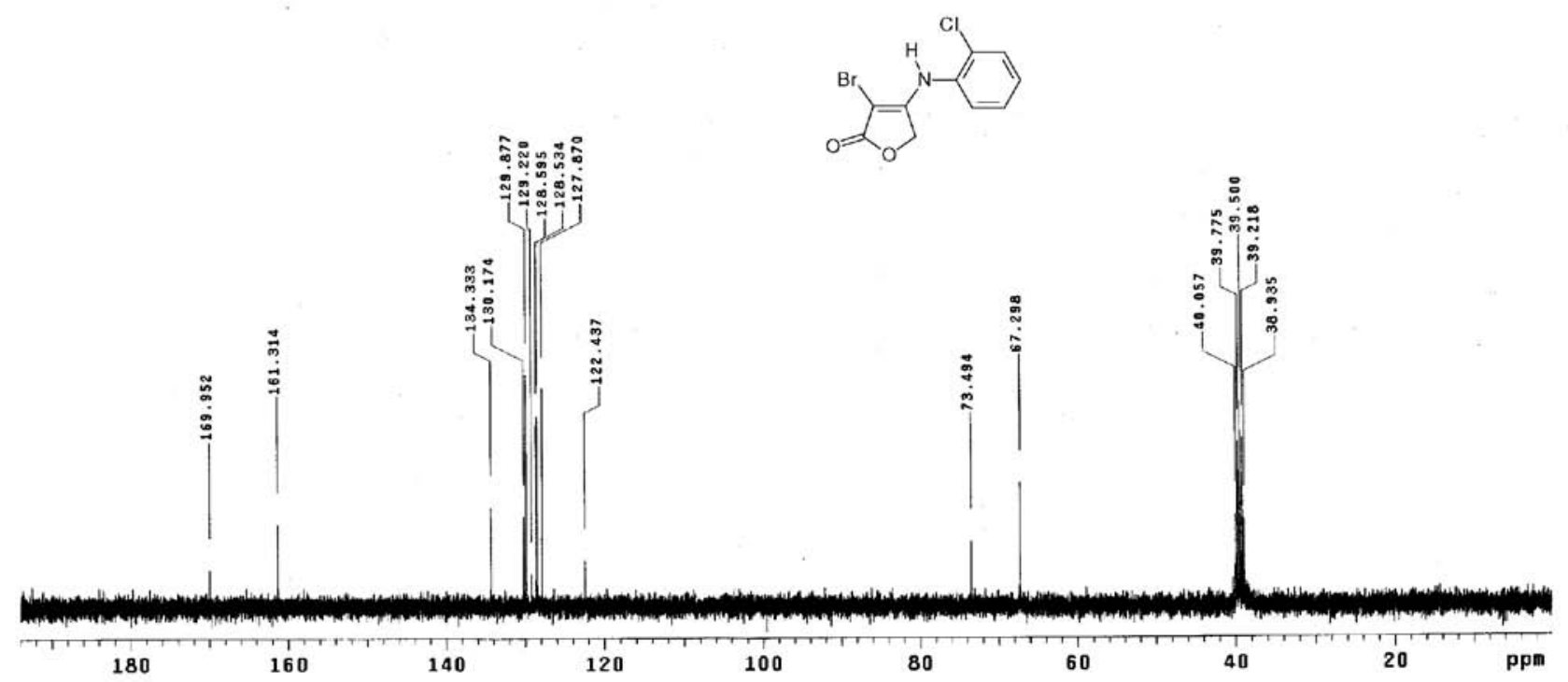

Figure S16. Full ${ }^{13} \mathrm{C}$ NMR spectrum of compound $\mathbf{3 h}\left(\mathrm{CDCl}_{3}\right)$. 

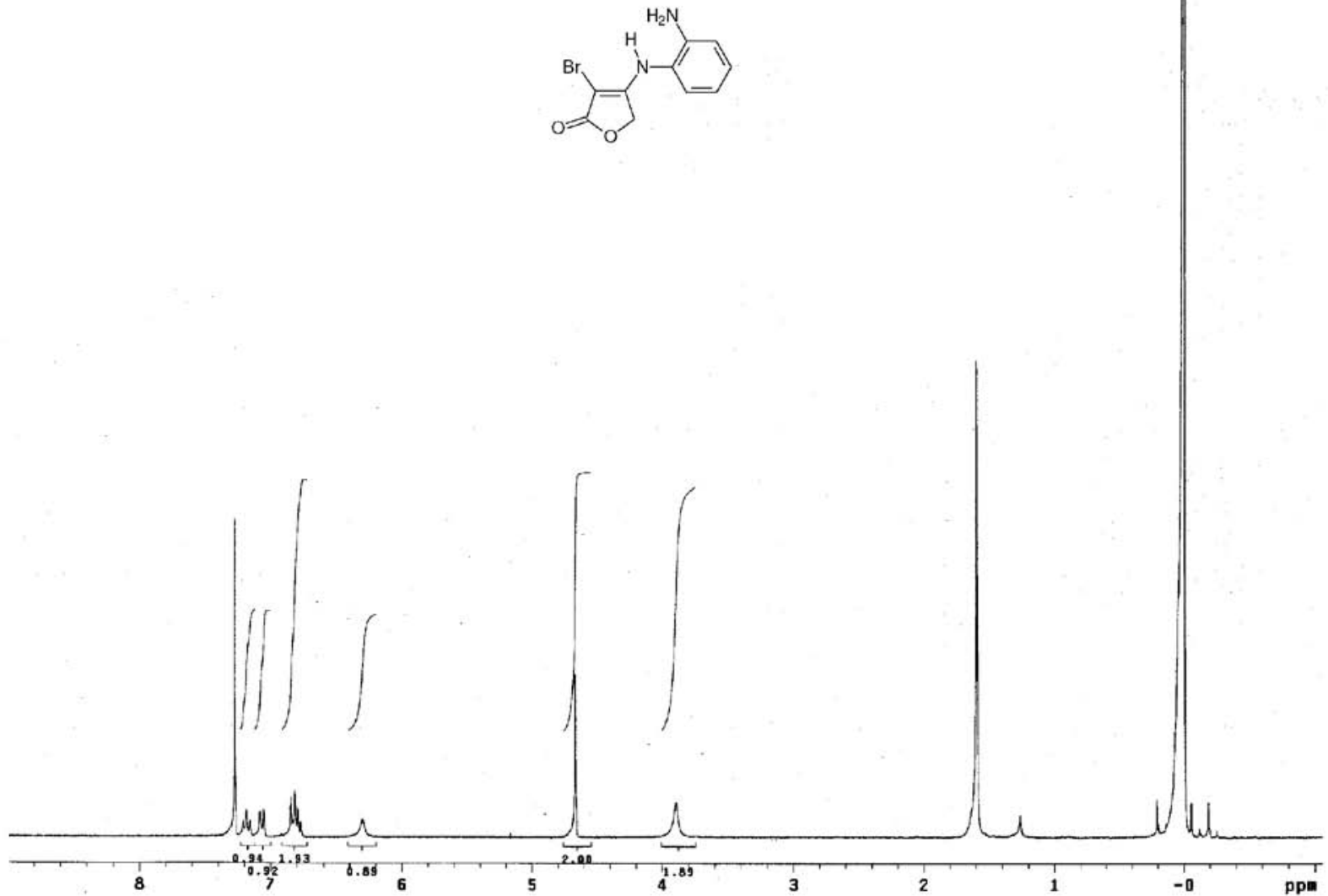

Figure S17. Full ${ }^{1} \mathrm{H}$ NMR spectrum of compound $3 \mathbf{i}\left(\mathrm{CDCl}_{3}\right)$.

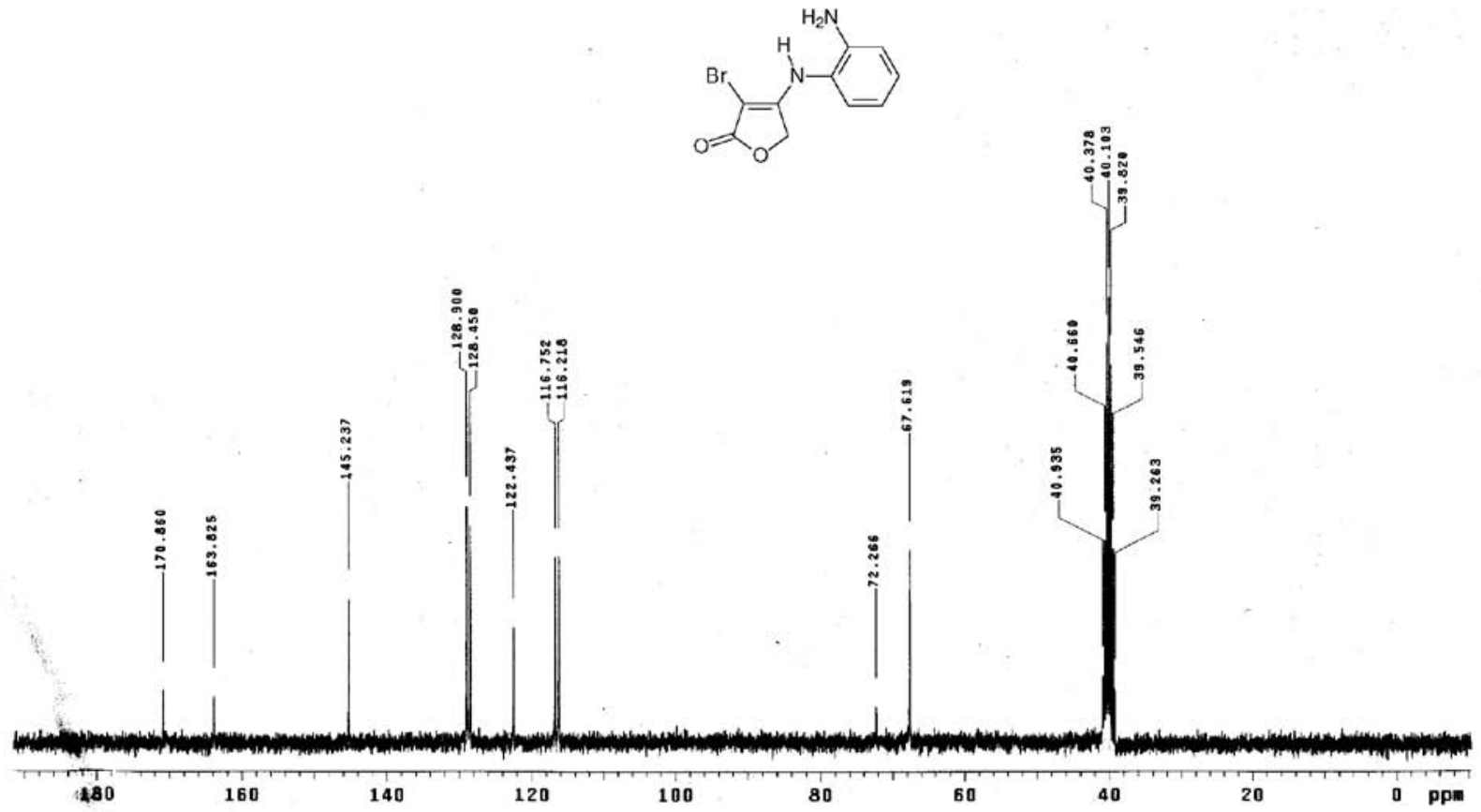

Figure S18. Full ${ }^{13} \mathrm{C}$ NMR spectrum of compound 3i (DMSO- $d 6$ ). 


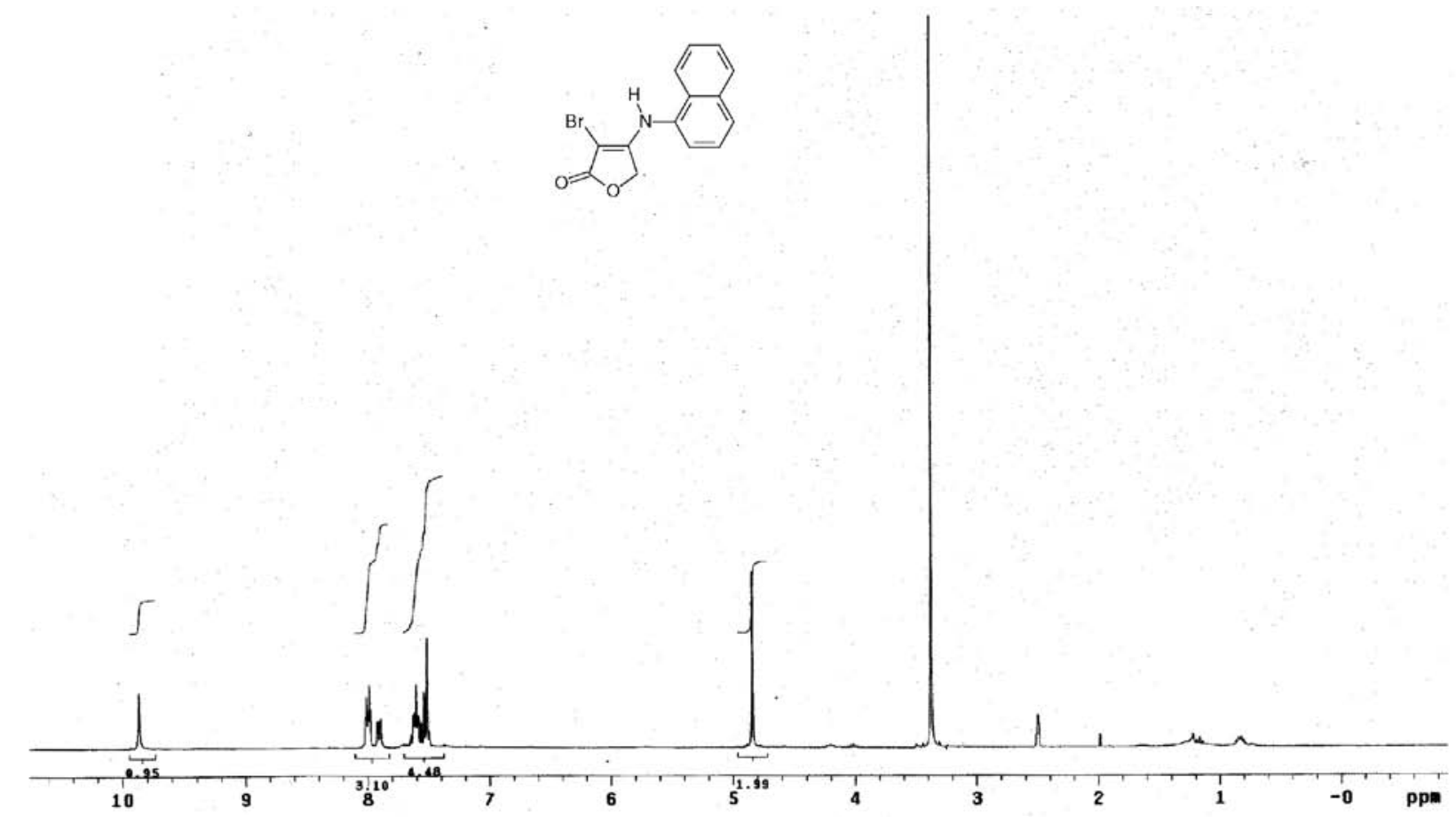

Figure S19. Full ${ }^{1} \mathrm{H}$ NMR spectrum of compound $\mathbf{3 j}\left(\mathrm{CDCl}_{3}\right)$.

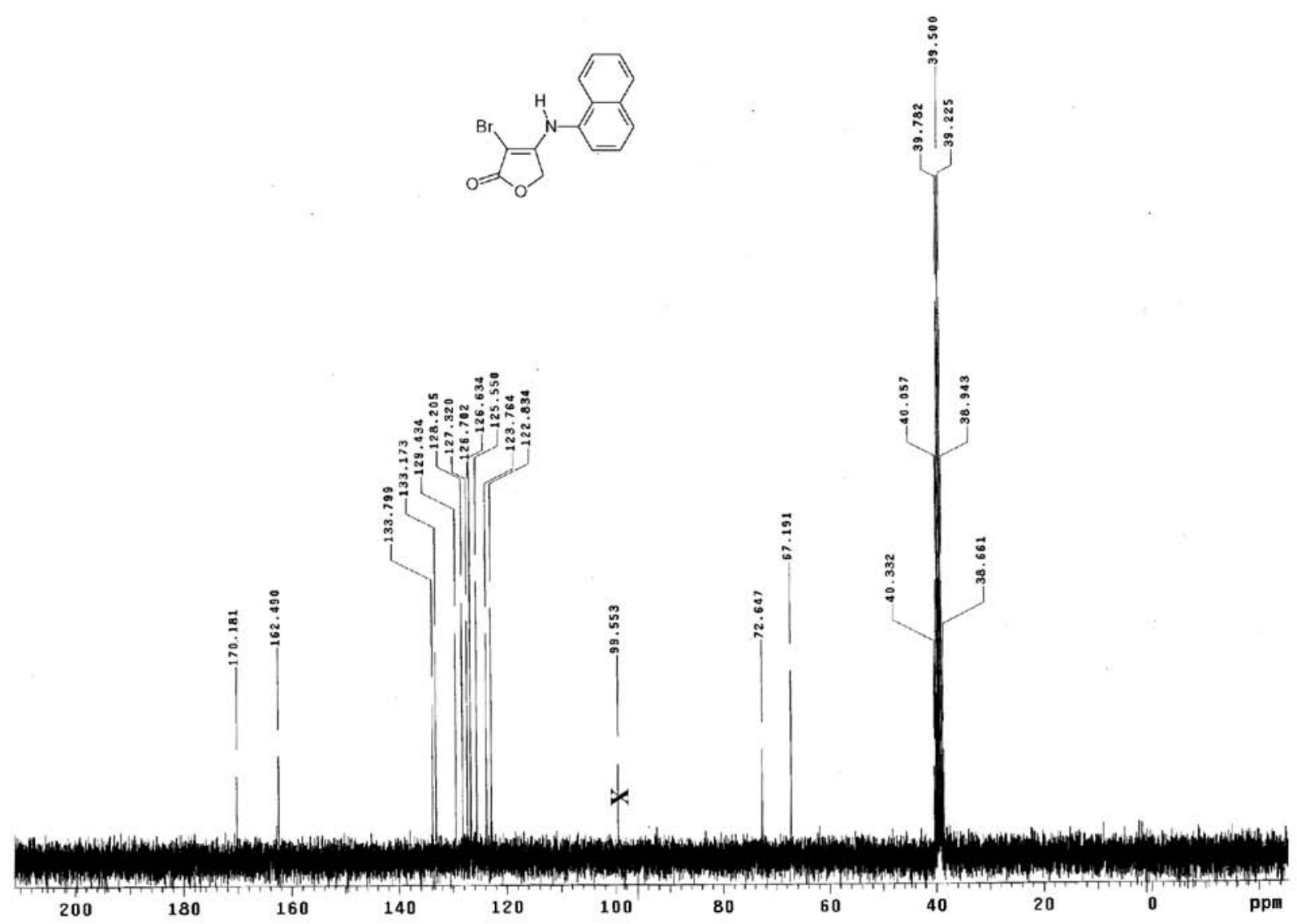

Figure S20. Full ${ }^{13} \mathrm{C}$ NMR spectrum of compound $\mathbf{3 j}\left(\mathrm{CDCl}_{3}\right)$. 